\title{
Cutaneous wound healing: recruiting developmental pathways for regeneration
}

\author{
Kirsten A. Bielefeld · Saeid Amini-Nik • \\ Benjamin A. Alman
}

Received: 31 January 2012/Revised: 29 August 2012/ Accepted: 30 August 2012/Published online: 4 October 2012

(C) The Author(s) 2012. This article is published with open access at Springerlink.com

\begin{abstract}
Following a skin injury, the damaged tissue is repaired through the coordinated biological actions that constitute the cutaneous healing response. In mammals, repaired skin is not identical to intact uninjured skin, however, and this disparity may be caused by differences in the mechanisms that regulate postnatal cutaneous wound repair compared to embryonic skin development. Improving our understanding of the molecular pathways that are involved in these processes is essential to generate new therapies for wound healing complications. Here we focus on the roles of several key developmental signaling pathways (Wnt/ $\beta$-catenin, TGF- $\beta$, Hedgehog, Notch) in mammalian cutaneous wound repair, and compare this to their function in skin development. We discuss the varying responses to cutaneous injury across the taxa, ranging from complete regeneration to scar tissue formation. Finally, we
\end{abstract}

K. A. Bielefeld and S. Amini-Nik are co-first authors.

K. A. Bielefeld · S. Amini-Nik · B. A. Alman $(\bowtie)$

Program in Developmental and Stem Cell Biology, Department of Developmental and Stem Cell Biology, Hospital for Sick Children Research Institute, Toronto Medical Discovery Tower, East Tower, 101 College St., Toronto, ON M5G 1L7, Canada e-mail: benjamin.alman@sickkids.ca

K. A. Bielefeld

e-mail: kirsten.bielefeld@mail.utoronto.ca

S. Amini-Nik

e-mail: saeid.amininik@utoronto.ca

K. A. Bielefeld · B. A. Alman

Department of Laboratory Medicine and Pathobiology, University of Toronto, Toronto, ON M5S 1A8, Canada

B. A. Alman

Department of Surgery, University of Toronto,

Toronto, ON M5S 1A8, Canada outline how research into the role of developmental pathways during skin repair has contributed to current wound therapies, and holds potential for the development of more effective treatments.

Keywords Wound healing - Regeneration - Skin . Wnt $\cdot \beta$-Catenin · Transforming growth factor $\beta$ (TGF- $\beta$ ) . Notch $\cdot$ Hedgehog

\section{Cutaneous wund healing and skin development}

Cutaneous wound repair recapitulates embryonic skin development in numerous aspects, in an attempt to restore the integrity of the injured tissue. Both processes involve the differentiation, migration, proliferation, and apoptosis of various cell types to create the multilayered tissue that constitutes the skin. Many of the same key signaling pathways that are activated during embryonic skin development are also activated during postnatal cutaneous wound repair; these include the Wnt/ $\beta$-catenin, Notch, Hedgehog, and various growth factor/cytokine pathways. Furthermore, several 'embryonic' extracellular matrix (ECM) components, such as Extra-Domain-A (EDA) fibronectin, are synthesized during postnatal wound repair [1,2]. Despite these similarities, there are a number of important differences between the molecular mechanisms that regulate postnatal cutaneous wound repair and embryonic skin development, and these may partly be responsible for the inability of repaired skin to achieve its original uninjured state.

Repaired skin, which usually heals as a scar, is weaker than intact skin, and contains a disorganized ECM compared to nonwounded skin, and healing early gestational fetal wounds [3-6]. Cutaneous wounds do not normally show regeneration of hair follicles, although an exception 
has been documented in the case of large cutaneous wounds [7]. As a result, postnatal mammalian skin repair is not identical to the process of regeneration, in which the regenerated tissue is almost indistinguishable from the uninjured tissue $[5,8]$. Part of the reason for this difference is the inflammatory response, which is unique to postnatal wound healing [4, 9]. While the inflammatory response is crucial to protect the body from invading foreign organisms at the injury site, many of the inflammatory cytokines and growth factors released during this process promote fibrosis and scar formation [10, 11]. Indeed, embryonic wounds tend to heal without scarring, and it is believed that this is due to the relative lack of an inflammatory response caused by the absence of a fully developed immune system [4, 5, 9]. Though early fetal healing does incorporate growth factors and cytokines, the expression profiles and concentrations of these molecules are different from those in scarforming late gestational and adult healing [4, 6, 9]. For example, scarless fetal wound healing is characterized by lower levels of transforming growth factor- $\beta 1$ (TGF- $\beta 1$ ), and higher concentrations of TGF- $\beta 3$, compared to scarforming wounds $[6,9]$. Similarly, the composition and/or levels of certain ECM components, such as hyaluronic acid, fibronectin, and elastin, differ in fetal versus postnatal skin $[9,12,13]$, and may influence the healing outcome.

Additional insight into the mechanisms that cause embryonic skin development and repair to differ from postnatal mammalian skin healing are being elucidated by studies of organisms such as amphibians, which regenerate their injured tissue in a process analogous to development [5, 8]. Enhancing our understanding of the molecular pathways that are responsible for these differences is vital for generating novel medical therapies to improve wound healing and reduce scarring. Here, we discuss the role of developmental signaling pathways in cutaneous wound repair, with an emphasis on keratinocyte and fibroblast behavior, and compare and contrast this with their roles in skin development. We also outline the varying responses to injury across the taxa, ranging from complete regeneration to scar tissue formation. Finally, we discuss current clinical applications that may improve wound healing via the modulation of developmental pathways, and map out future areas of research which remain to be addressed.

\section{Stages of cutaneous wound healing}

The skin is composed of two main layers: the superficial layer, the epidermis, which functions as a barrier to the external environment, and the deeper layer, the dermis, which is composed of connective tissue, and provides the skin with its mechanical properties. The epidermis consists of a stratified keratinized epithelium that is interspersed with hair follicles and glands [14-16]. Underlying the

Table 1 Summary of the stages of wound repair

\begin{tabular}{|c|c|c|}
\hline Stage of healing & Main processes & References \\
\hline Hemostasis and inflammation & $\begin{array}{l}\text { Hemostasis } \\
\text { Vasoconstriction } \\
\text { Formation of fibrin clot } \\
\text { Inflammation } \\
\text { Release of cytokines and growth factors by platelets and immune } \\
\text { cells, and from the disrupted matrix } \\
\text { Invasion of inflammatory cells (neutrophils, monocytes- } \\
\text { macrophages) }\end{array}$ & {$[3,15,17-19]$} \\
\hline Proliferation & $\begin{array}{l}\text { Dermis } \\
\text { Release of growth factors by macrophages and fibroblasts } \\
\text { Fibroblast migration and proliferation } \\
\text { Synthesis of matrix proteins (fibronectin and collagen) } \\
\text { Angiogenesis } \\
\text { Epidermis } \\
\text { Keratinocyte migration, proliferation and differentiation } \\
\text { Contributions from hair follicle stem cells } \\
\text { Possible contribution from interfollicular epidermal stem cells }\end{array}$ & {$[1-3,5,15,20,23,25,27,28,30]$} \\
\hline Remodeling & $\begin{array}{l}\text { Reorganization and remodeling of the ECM } \\
\text { Myofibroblast formation } \\
\text { Contraction of the wound } \\
\text { Cell apoptosis }\end{array}$ & {$[3,5,18,20,32,33]$} \\
\hline
\end{tabular}


epidermis is the dermis, subdivided into the upper 'papillary' dermis, and the lower 'reticular' dermis, which differ in the density of their collagen fibers [16]. During cutaneous wound healing, the barrier and mechanical properties of skin are restored by the actions of numerous cell types which undergo proliferation, differentiation, migration and apoptosis to rebuild the skin. Normal cutaneous wound repair is characterized by three overlapping phases of healing termed the inflammatory, proliferative, and remodeling phases $[3,5,14,15]$ (Table 1; Fig. 1a).

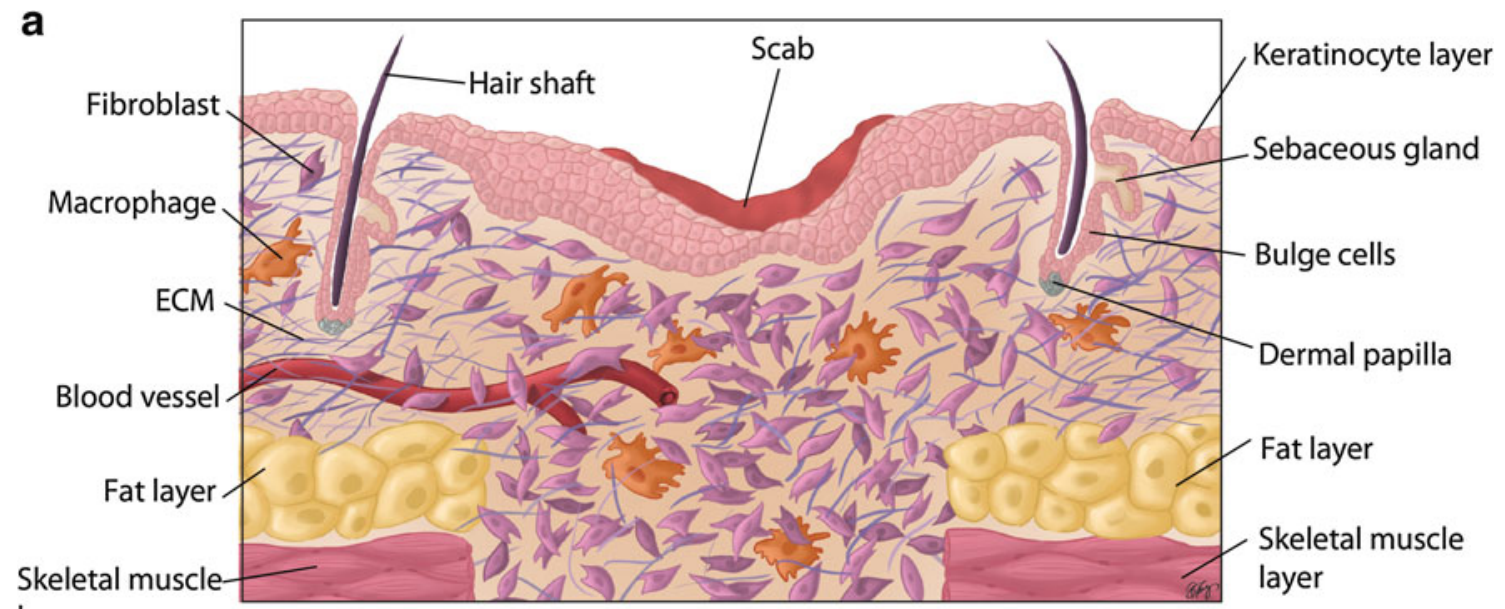

layer
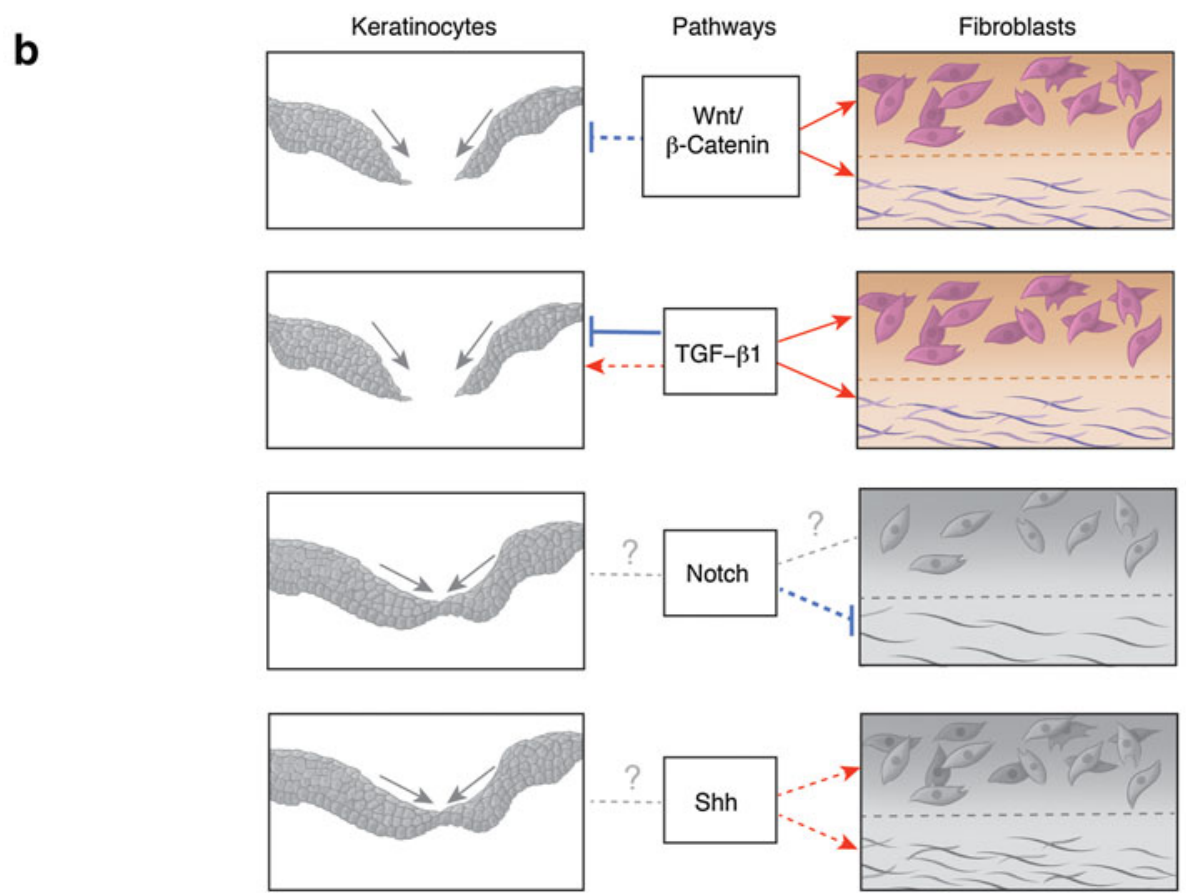

Fig. 1 Proliferative phase of murine cutaneous wound healing. a Illustrative histological section of a murine cutaneous wound during the proliferative phase of repair. Healing dermis is enriched with higher numbers of fibroblasts and macrophages compared to intact skin. b The effect of the developmental signaling pathways on keratinocyte behavior in epidermal closure, and fibroblast behavior and matrix deposition in dermal reconstitution, respectively, is depicted. Red arrows indicate a positive or stimulatory effect of a pathway on a cell type/outcome. Blue "inhibitory" symbols indicate an inhibitory effect. Solid lines indicate that the effect of a pathway on each cell type and/or outcome is supported by substantial in vivo evidence in the literature. Dotted lines indicate effects which either lack sufficient in vivo evidence or are based mainly on in vitro work. Dotted gray lines with a question mark indicate unknown or unclear outcomes. Colored diagrams represent outcomes of pathways in each cell type (or matrix deposition) that are supported by substantial in vivo evidence in the literature. In contrast, gray diagrams represent outcomes that are based mainly on in vitro evidence or require further in vivo investigation; Gray diagrams linked by a simple dotted line indicate that there is either no effect, or that the effect is not known. Refer to the text for a detailed explanation of the effect of each signaling pathway on keratinocyte and fibroblast behavior during wound repair 


\section{Hemostasis and inflammation}

Hemostasis forms the immediate response to injury and functions to prevent the loss of blood at the wound site. Vascular injury initiates a cascade of events that terminates in coagulation, and encompasses vascular constriction, platelet aggregation and degranulation, and finally the formation of a fibrin clot $[3,17,18]$. The fibrin clot also acts as a provisional matrix for the initial migration of inflammatory cells to the wound site $[3,17,18]$. Inflammatory cells, such as neutrophils and monocytes, are attracted to the site of injury by cytokines, including TGF$\beta$ and platelet-derived growth factor (PDGF), which are released by platelets and from sites of sequestration in the disrupted ECM $[15,17]$. Neutrophils remove bacteria and/ or foreign objects from the wound and are followed by monocytes, which subsequently differentiate into macrophages [19]. While macrophages phagocytose foreign organisms, particles, and dead neutrophils, they also release TGF- $\beta$ and other cytokines, and thereby stimulate the movement of fibroblasts and epithelial cells into the wound $[15,19]$.

\section{Proliferation}

The proliferative phase of wound healing (Fig. 1a) is characterized by re-epithelialization of the epidermis, and by repair of the underlying dermal or mesenchymal layer. This is accompanied by neovascularization. The dermis is restored by invading and proliferating fibroblasts that synthesize and secrete ECM proteins and also release activating growth factors such as TGF- $\beta 1[3,11,20]$. During the proliferative phase of wound repair, fibroblasts produce immature or 'embryonic' ECM variants such as EDA fibronectin and type III collagen, as well as the collagen type I that is normally found in adult skin $[1-3,20]$. The invasion of fibroblasts into the wound is facilitated by their secretion of ECM-cleaving matrix metalloproteinases (MMPs) [15]. Epidermal keratinocytes express various integrin receptors during wound repair and are thought to use the provisional matrix as a substrate for re-epithelialization [21,22]. Closure of the epithelial gap and restoration of the epithelium is important as a barrier function, and this is achieved by a combination of keratinocyte migration, proliferation and differentiation [5, 23]. Different populations of hair follicle stem cells [24-26], both inside [27] and outside of [28] the hair follicle bulge region, contribute to re-epithelialization during wound repair. Interfollicular epidermal stem cells $[24,29]$ may also participate in this process. For example, Langton et al. [30] found that the tail skin of wounded mutant mice that lack hair follicles still exhibited (albeit delayed) re-epithelialization. However, further research is needed to unravel the details of a potential contribution by interfollicular stem cells during wound healing.

\section{Remodeling}

The remodeling of the wound site, following deposition of sufficient ECM and the closure of the epithelial gap, changes the properties of the tissue. Wound fibroblasts at this stage of the repair process tend to adopt a contractile myofibroblast phenotype [31, 32]. Reorganization of the wound tissue involves the degradation and replacement of immature ECM such as EDA fibronectin and collagen type III with collagen I, the organization of collagen I fibers into bundles, and the apoptosis of a variety of cell types at the wound site $[3,5,15,18,20,33]$. Together, these changes result in the contraction of the wound and the formation of acellular scar tissue. The remodeling process can continue indefinitely, and scar tissue does not achieve the strength of intact uninjured skin [3, 15].

\section{Developmental signaling pathways in mammalian wound healing}

Wnt and $\beta$-catenin signaling

Wnts are secreted glycoproteins that are important in many fundamental cellular processes during development and in the maintenance of homeostasis in the adult (reviewed in references [34-37]). Wnt ligands signal through the canonical or noncanonical Wnt signaling pathways, depending on the context. The canonical Wnt signaling pathway is mediated through $\beta$-catenin, while the noncanonical Wnt signaling pathways, such as the planar-cellpolarity and the Wnt-calcium pathway, are transduced by alternate effectors independently of $\beta$-catenin $[35,38]$. Here we focus on the canonical Wnt signaling pathway and its key mediator, $\beta$-catenin (Fig. 1b; Table 2).

$\beta$-Catenin is a transcriptional coactivator that associates with other transcription cofactors, such as the T cell factors/ lymphoid enhancer factors, to modulate gene expression in a cell type-specific manner (reviewed in reference [36]). In the absence of Wnt signaling, $\beta$-catenin is targeted for proteasomal degradation via $\mathrm{N}$-terminal serine and threonine phosphorylation by a cytoplasmic destruction complex that includes the factors casein kinase I, axin, adenomatous polyposis coli protein, and glycogen synthase kinase (GSK) $3 \beta$ [34-37]. GSK3 $\beta$ is a crucial signaling hub that lies downstream of Wnt, growth factor, and integrin signaling pathways, among others [39], and its activity, and thus that of $\beta$-catenin, can also be regulated by these various pathways. Canonical Wnt signaling is initiated by Wnt binding to membrane Frizzled and low-density lipoprotein receptor 
Table 2 Comparative summary of the participation of developmental signaling pathways in mammalian skin development and repair

\begin{tabular}{|c|c|c|c|}
\hline Signaling pathway & Skin compartment ${ }^{\mathrm{a}}$ & Skin development & Skin repair \\
\hline \multirow[t]{2}{*}{$\mathrm{Wnt} / \beta$-catenin } & Dermis & $\begin{array}{l}\text { Development of the dermis } \\
{[41,43,44]}\end{array}$ & $\begin{array}{l}\text { Reconstitution of the dermis: fibroblast } \\
\text { numbers, cellularity; fibroblast behavior; } \\
\text { matrix production }[53,55,56,58,60,62]\end{array}$ \\
\hline & $\begin{array}{l}\text { Epidermis and associated } \\
\text { structures }\end{array}$ & $\begin{array}{l}\text { Development and morphogenesis } \\
\text { of hair follicles }[24,26,46-48]\end{array}$ & Regeneration of hair follicles in large wounds [7] \\
\hline \multirow[t]{2}{*}{ TGF- $\beta 1$} & Dermis & $\begin{array}{l}\text { Role to be deciphered; expressed } \\
\text { in developing dermis }[217,218]\end{array}$ & $\begin{array}{l}\text { Reconstitution of the dermis; fibroblast proliferation } \\
\text { and behavior; matrix production; myofibroblast } \\
\text { formation; wound contraction }[87-89,91,92, \\
100-102,107]\end{array}$ \\
\hline & $\begin{array}{l}\text { Epidermis and associated } \\
\text { structures }\end{array}$ & $\begin{array}{l}\text { No significant role in hair follicle } \\
\text { development [84] }\end{array}$ & Inhibitory role in re-epithelialization $[92,102,106]$ \\
\hline \multirow[t]{2}{*}{ Notch } & Dermis & Role to be deciphered & $\begin{array}{l}\text { May be involved in dermal reconstitution: } \\
\text { macrophage behavior [130]; angiogenesis } \\
\text { [129-131]; effect on matrix [130] }\end{array}$ \\
\hline & $\begin{array}{l}\text { Epidermis and associated } \\
\text { structures }\end{array}$ & $\begin{array}{l}\text { Epidermal differentiation } \\
{[26,123-125]}\end{array}$ & Role to be deciphered \\
\hline \multirow[t]{2}{*}{ Sonic hedgehog } & Dermis & $\begin{array}{l}\text { Role to be deciphered; in non- } \\
\text { mammals (chick embryo), it } \\
\text { does not induce differentiation } \\
\text { of dermatome (precursor of } \\
\text { dermis) [219] }\end{array}$ & $\begin{array}{l}\text { May be involved in dermal reconstitution: } \\
\text { effects on matrix, vascularity, and cellularity } \\
{[140,141]}\end{array}$ \\
\hline & $\begin{array}{l}\text { Epidermis and associated } \\
\text { structures }\end{array}$ & $\begin{array}{l}\text { Development and morphogenesis } \\
\text { of hair follicles [46, 132, 134, } \\
135,138]\end{array}$ & $\begin{array}{l}\text { Present in regenerated hair follicles } \\
\text { [7]; not expressed by wound } \\
\text { keratinocytes [142] }\end{array}$ \\
\hline
\end{tabular}

a "Epidermis and associated structures" includes the hair follicle and its associated structures (such as the dermal papilla).

related protein 5/6 (LRP 5/6), which stimulates the downstream signaling mediator, Dishevelled [34-37]. Dishevelled in turn stabilizes $\beta$-catenin by inhibiting the activity of its destruction complex [35], leading to increased cytoplasmic and nuclear levels of $\beta$-catenin. In addition to its role as a signaling molecule, $\beta$-catenin functions as a structural protein and forms a component of the adherens junctions that mediate cell-cell contacts $[34,40]$. It can be freed from this physical association by phosphorylation at specific tyrosine residues [40].

Wnts are important mediators of skin development, participating in various processes from development of the dermis to the formation of skin appendages, such as hair (reviewed in reference [41]). Dermis at different sites in the body, such as the dorsal and ventral dermis, has different origins, and dermal development precedes that of the skin appendages $[41,42]$. Canonical $\mathrm{Wnt} / \beta$-catenin signaling is required for the specification of both murine dorsal [43] and ventral [44] dermis. In murine ventral dermis formation, $\beta$-catenin also plays a role in the survival of early ventral dermal progenitor cells [44]. Later in embryonic development, epithelial-mesenchymal interactions lead to the formation of the hair follicle from the epidermal placode, the precursor of the hair follicle [24, 41, 45]. Wnt/ $\beta$-catenin is essential for hair follicle development during embryogenesis [24, 26, 46-48]. In addition, it is important for differentiation of hair follicles postnatally [24, 26, 46, $49,50]$.

Analogous to its function in skin development, Wnt and/ or $\beta$-catenin signaling plays an important role in various aspects of cutaneous wound repair. As discussed below, it is involved in the construction of epithelial structures and in the reconstitution of the dermal compartment, where $\beta$-catenin is a prominent regulator of fibroblast behavior.

Cutaneous wounds express various Wnts during the early phases of healing, with transcripts from Wnts $1,3,4$, $5 \mathrm{a}$, and $10 \mathrm{~b}$ present in murine whole cutaneous wounds up to 7 days after wounding [51]. In the epithelium, Wnt10b protein can be detected in migrating epithelial cells up to 3 days after wounding, while WNT $4,5 \mathrm{a}$, and 10b localize to hair follicles [51]. Wnt 4 is expressed in the dermis, although the time-course of its expression has been variously detected in different studies up to $30 \mathrm{~h}$ after wounding [52] and up to 7 days after wounding [51].

Wnt signaling is crucial to the regeneration of hair follicles following injury-a process which has been documented only in large healing wounds [7]. The concept that wound healing recapitulates embryonic development is illustrated by the interesting finding that the source of new follicles is not cells within the hair follicle stem cell niche [7]. This suggests that injury can reprogram or endow other epidermal cells with stem cell or embryonic properties [7]. 
The role of $\mathrm{Wnt} / \beta$-catenin signaling in wound re-epithelialization is beginning to be unraveled. Primary keratinocytes harvested from mice expressing conditionally ablated or stabilized $\beta$-catenin alleles do not display significant differences in migratory capacity in in vitro experiments [53]. An inhibitory effect of $\beta$-catenin on re-epithelialization has been suggested by a study that observed enhanced epidermal nuclear accumulation of $\beta$-catenin at the edge of chronic ulcers [54], and found that pharmacological stabilization of $\beta$-catenin inhibited keratinocyte migration in culture [54]. Though these studies suggest that $\beta$-catenin does not promote keratinocyte migration in vitro, further research is needed to elucidate whether $\beta$-catenin or Wnt signaling actively influences re-epithelialization of wounds in vivo.

$\beta$-Catenin is an important regulator of fibroblast behavior during the proliferative phase of dermal wound repair. $\beta$-Catenin protein levels and transcriptional activity are elevated in dermal fibroblasts during the proliferative phase of healing in murine cutaneous wounds and return to baseline during the remodeling phase [55]. Human wounds similarly show increased expression of $\beta$-catenin and its target genes, such as fibronectin and MMP7, during the proliferative phase [56]. Increased $\beta$-catenin expression during wound repair has also been noted in other species, such as in the horse [57]. The relative level and activity of $\beta$-catenin contributes to the dermal wound phenotype, with high $\beta$-catenin levels and activity leading to an enlarged, hypercellular dermal compartment, and low levels of $\beta$-catenin associated with a smaller and less cellular dermal compartment [53]. This was demonstrated using mouse models in which $\beta$-catenin can be conditionally stabilized or ablated [53]. Similar to the hyperproliferative dermal healing response that is observed in conditionally $\beta$-catenin stabilized mice [53], mice with a fibroblast-specific conditional deletion of GSK $3 \beta$ show elevated $\beta$-catenin levels and a rapid and fibrotic wound healing response, that includes increased dermal collagen deposition, scarring, and myofibroblast formation [58]. The mechanism was found to involve a $\beta$-catenin-dependent pathway $[58,59]$. It has been recently shown that knockdown of $\beta$-catenin in Pax7-expressing cells in murine wounds results in a smaller scar size with fewer dermal fibroblast-like cells [60]. In fact, approximately $25 \%$ of dermal fibroblast-like cells in healing wounds in mice are derived from Pax7expressing muscle progenitor cells that exhibit activated $\beta$-catenin signaling [60]. While increased $\beta$-catenin activity during the proliferative phase is crucial for successful wound repair, prolonged or aberrant $\beta$-catenin activity beyond the normal parameters of healing contributes to excessive fibrosis and scar formation. Indeed human hypertrophic scars and keloids exhibit elevated $\beta$-catenin levels [56, 61].
Interestingly, while Wnt ligands may participate in stimulating dermal $\beta$-catenin during wound repair, Wnt signaling is not crucial for maintaining elevated $\beta$-catenin levels during the proliferative phase of cutaneous healing [62]. This has been demonstrated in mice treated with an adenovirus expressing the Wnt signaling inhibitor Dickkopf (DKK1, which binds LRP6/Arrow [63]), which did not show a significant decline in $\beta$-catenin protein levels during the proliferative phase of skin wound healing [62], in contrast to the situation in bone repair [64]. This suggests that other factors play a role in regulating $\beta$-catenin levels during the proliferative phase of healing. Indeed, $\beta$-catenin levels in fibroblasts can be stimulated by growth factors, such as TGF- $\beta 1[53,65,66]$, that are released during the early stages of wound repair. Furthermore, $\beta$-catenin activity in dermal fibroblasts is regulated by ECM components, such as fibronectin, which activate $\beta$-catenin through a GSK3 $\beta$-dependent, $\beta 1$ integrin-mediated pathway [62]. Integrins, which span the cell membrane, are one of the major pathways of communication between the ECM and the cell interior [67, 68]. During the proliferative phase of wound repair, EDA fibronectin-deficient mice display reduced $\beta$-catenin activation, fewer fibroblasts, and decreased wound strength compared to wild-type littermates [62]. These characteristics are rescued by genetic activation of $\beta$-catenin using an EDA fibronectin-deficient mouse cross that also expresses conditionally stabilized $\beta$-catenin, or through pharmacological stabilization of $\beta$-catenin using lithium chloride [62]. This suggests that fibronectin regulates fibroblast behavior through a $\beta$-catenin mediated mechanism during wound repair [62]. ECM regulation of $\beta$-catenin during wound healing has also been suggested by the finding that wounds created by the novel Picsecond IR laser, which causes minimal tissue or ECM damage compared to traditional surgical lasers, show decreased $\beta$-catenin and TGF- $\beta$ pathway activation compared to wounds created using a surgical scalpel [69].

Mesenchymal progenitor cells also contribute to repair in various contexts $[70,71]$. As the differentiation state of mesenchymal progenitor cells is tightly regulated by Wnt/ $\beta$-catenin signaling [70-72], changes in the level of signaling activity may affect the repair process by impacting differentiation of these cells. For instance, in bone repair, altering $\beta$-catenin levels before pluripotent mesenchymal progenitors cells have differentiated impairs healing [64]. In contrast, activating $\beta$-catenin levels once progenitors have committed to the osteoblast lineage has a positive effect on repair [64]. The impact of $\mathrm{Wnt} / \beta$-catenin signaling levels on mesenchymal progenitor differentiation is also illustrated in the context of myocardial healing: in an implantation model of myocardial repair, inhibition of Wnt (and bone morphogenetic protein, BMP) signaling using 
secreted frizzled-related protein-2 prevents differentiation and apoptosis of bone marrow-derived mesenchymal progenitor cells and improves their engraftment [73].

$\beta$-Catenin and Wnt signaling are intrinsically involved in the formation of the dermis and of epidermal structures, both during wound repair and during skin development. It will be interesting to elucidate whether non-Wnt activators of $\beta$-catenin, such as ECM proteins and growth factors, modulate $\beta$-catenin during skin development as they do during healing. In turn, the role of $\mathrm{Wnt} / \beta$-catenin signaling in terms of epidermal-mesenchymal interactions during wound repair must be further explored. These reciprocal interactions play a significant role during embryonic skin development [41, 45], but have not yet been as thoroughly investigated during wound healing. A recent study demonstrated that adult dermis can be reprogrammed to regain the characteristics of neonatal dermis in response to epidermal stabilization of $\beta$-catenin [74], raising the issue of whether similar or reciprocal interactions could take place during wound repair. In that study, the remodeled dermis was characterized by a downregulation of ECM genes, expression of immature collagens, and increased proliferation of fibroblasts, and these responses were found to originate from fibroblasts in the vicinity of the sebaceous gland [74]. Another example of epidermal-mesenchymal interactions in skin is illustrated by the finding that epidermal hair follicle stem cells secrete the $\mathrm{Wnt} / \beta$-catenin target, Nephronectin, to form a specialized attachment site for smooth muscle precursors of the arrector pili muscle [75]. Thus, investigating whether Wnt and/or $\beta$-catenin participate in epithelial-mesenchymal interactions during wound repair is an important direction for future research.

\section{TGF- $\beta$ pathway}

Numerous growth factors and cytokines participate in wound repair. These include the TGF- $\beta$ s, PDGFs, epidermal growth factors (EGFs), fibroblast growth factors (FGFs), vascular endothelial growth factors (VEGFs), and various proinflammatory cytokines, such as the interleukins (reviewed in references [76, 77]). These factors are released by various cell types as well as from sites of sequestration in the disrupted ECM [77]. In this review, we focus on TGF- $\beta \mathrm{s}$, which are one of the major cytokine mediators of cutaneous wound healing.

TGF- $\beta$ s comprise the TGF- $\beta 1$, TGF- $\beta 2$ and TGF- $\beta 3$ isoforms, and are part of the TGF- $\beta$ superfamily that also includes BMPs, among others [10, 78]. During wound healing, TGF- $\beta \mathrm{s}$ are secreted by various cell types, including macrophages and fibroblasts, and they are also released from storage sites in the disrupted ECM [77, 79]. TGF- $\beta$ s are secreted as inactive precursors bound to the latency-associated and latent TGF- $\beta$ binding proteins
$[10,79]$. They are subsequently activated by the action of proteases or through conformational changes induced by integrins in response to cell traction forces [10, 79]. TGF- $\beta$ s exert cell-specific effects by binding to serine/ threonine kinase TGF- $\beta$ receptor I and TGF- $\beta$-receptor II heterodimers, leading to the activation (phosphorylation) of Smads 2 and 3, their association with the common mediator Smad 4, and the subsequent translocation of this complex to the nucleus where they may associate with other transcription cofactors to modulate gene expression [10, 11, 78-80]. Smad 7 is an antagonist to Smad 2/3-mediated signaling [10, 11, 78-80]. Mechanisms of TGF- $\beta$ signaling that do not involve Smads also exist, including mitogen-activated protein kinase, Akt, extracellular signal-regulated kinase, TGF- $\beta$-associated kinase I, and small GTPases, among others [81-83].

Several members of the TGF- $\beta$ superfamily, including TGF- $\beta$ s and BMPs, are involved in the development of skin and/or skin appendages, such as hair follicles [78]. Studies involving mice deficient in different TGF- $\beta$ isoforms have shown that TGF- $\beta 2$ is required for murine hair follicle development, while TGF- $\beta 1$ and TGF- $\beta 3$ do not contribute significantly to this process [84]. In turn, addition of exogenous TGF- $\beta 1$ to embryonic skin explants has an inhibitory effect on hair follicle development [84]. Using a keratinocyte-specific Smad7-overexpressing mouse model, it was found that Smad-7 can interact with $\beta$-catenin to influence both embryonic and adult hair follicle morphogenesis by promoting its degradation via recruitment of the E3 ligase, Smurf 2 [85]. However, the relevance of this mechanism to hair follicle formation under normal physiological conditions must be further explored.

The TGF- $\beta$ pathway is recognized for its ability to alter the pace of healing. TGF- $\beta 1$ is characterized as a fibrosisand scar-promoting factor, while TGF- $\beta 3$ has been associated with antiscarring actions $[6,86]$. For instance, Puolakkainen et al. [87] found that treatment of wounds in aged rats with topical TGF- $\beta 1$ improved several aspects of dermal healing, including ECM deposition and fibroblast influx and proliferation. TGF- $\beta 1$ application also improved angiogenesis, inflammatory cell infiltration, and epithelial closure of the wounds [87]. Indeed, TGF- $\beta 1$ signaling plays a role in many fibrotic effects associated with wound repair, including proliferation of fibroblasts [87, 88], synthesis of ECM components such as collagen I [89] and fibronectin [89, 90] by fibroblasts, transition of fibroblasts to a myofibroblast wound phenotype [91], and contraction of the wound [92]. Some of the fibrotic effects of TGF- $\beta$ in wound fibroblasts may be mediated through the matricellular protein, connective tissue growth factor (CTGF or CCN2) [93-97]. CCN2 is upregulated in response to TGF- $\beta$ signaling in fibroblasts during fibrotic conditions 
such as wound repair, and it also cooperates with TGF- $\beta$ to mediate some of its effects, such as regulation of collagen expression [93, 94, 97-99].

In vivo animal models, particularly genetically modified mice, have contributed much of our understanding of the fibrotic mechanisms of the TGF- $\beta$ pathway during wound repair. Mouse models deficient in TGF- $\beta$ pathway signaling components tend to exhibit defects in dermal healing. For example, the dermis of Smad 3 knockout mice displays fewer fibroblasts, reduced ECM deposition, and a smaller wound area than control mice [100]. Similarly, wounds in

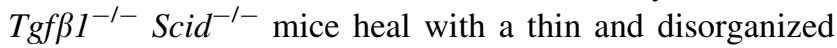
dermis, and exhibit delays in all phases of wound healing [101]. Both studies also showed a deficiency in inflammatory cells in the healing wounds [100, 101]. More recent studies have utilized fibroblast-specific deletions of TGF- $\beta$ receptor II (TGF- $\beta$ RII) to examine its effect on dermal healing $[92,102]$. These studies showed that ablation of fibroblast TGF- $\beta$ RII causes defects in the dermal ECM, such as a reduction in granulation tissue formation, increased scar size [102], and diminished collagen deposition [92]. Fibroblasts cultured from TGF- $\beta$ RII knockout mice also display cytoskeletal abnormalities, and reduced contractile abilities [92]. Thus, various mouse models clearly demonstrate that TGF- $\beta$ signaling is crucial in mediating the fibrotic mechanisms needed to restore the dermis during adult cutaneous wound repair.

While the profibrotic effects of TGF- $\beta 1$ suggest that it may promote re-epithelialization by stimulating matrix formation for keratinocyte migration, TGF- $\beta 1$ also has an inhibitory effect on keratinocyte proliferation [103], suggesting that it may impair this aspect of re-epithelialization. In keeping with these different effects of TGF- $\beta 1$ on keratinocytes, contrasting roles for TGF- $\beta$ pathway involvement in re-epithelialization have been described in the literature. For example, topical TGF- $\beta 1$ administration promotes epithelial wound closure in rats [87], and this is complimentary to the delayed re-epithelialization observed in double mutant $T g f \beta 1^{-1-} \mathrm{Scid}^{-1-}$ mice [101]. Similarly, the wounds of $\alpha 3 \beta 1$ integrin-deficient mice display a lag in re-epithelialization which is caused by a suppression of the response to TGF- $\beta 1$ signaling in keratinocytes via the upregulation of inhibitory Smad 7 [104]. In contrast to studies which have shown a positive role for the TGF- $\beta 1$ pathway in epidermal closure, other research has demonstrated a negative influence of TGF- $\beta 1$ signaling on reepithelialization. For example, deletion of $\mathrm{Smad} 3$ in genetically engineered mice results in accelerated epidermal closure and proliferation [100], and TGF- $\beta$ antagonist treatment of porcine burn wounds increased the number of wounds that healed with complete re-epithelialization [105]. Transgenic mice that overexpress the inhibitory Smad, Smad-7, in the epidermis also exhibited more rapid wound closure, increased keratinocyte proliferation, and in vitro keratinocyte migration than controls [106].

Because TGF- $\beta 1$ stimulates wound contraction [92, 107], it is possible that some of the seemingly contrasting roles for the TGF- $\beta$ pathway in re-epithelialization could be caused, in part, by effects on wound contraction being interpreted as epithelialization. Furthermore, different TGF- $\beta$ ligands and/or pathway components were manipulated in various studies, which may in turn result in different downstream effects. For instance, manipulation of a signaling mediator, such as Smad, affects the signaling of various upstream members of the TGF- $\beta$ superfamily, and thus influences the function of numerous pathways simultaneously. Crosstalk between different cell compartments, or the relative balance of other signaling mediators, may also be affected by different experimental conditions across studies. In fact, the ultimate effect of TGF- $\beta$ on re-epithelialization may be determined by the balance of a complex array of factors and conditions at the wound site.

TGF- $\beta$ signaling during wound healing involves crosstalk between the dermis and epidermis to influence the healing outcome [108]. For example, while fibroblasts release growth factors such as TGF- $\beta$ that affect keratinocyte behavior [103], keratinocytes can in turn downregulate TGF- $\beta$ expression by fibroblasts [109]. An influence of epidermal TGF- $\beta$ signaling on dermal healing is also suggested by a recent study in transgenic mice that over-express Smad7 in keratinocytes [106]. Cutaneous wounds from these mice exhibit altered temporal expression of dermal collagen compared to control mice, and effects on angiogenesis and inflammatory cells were also observed [106]. In turn, mouse models with a fibroblast-specific deletion of TGF- $\beta$ RII show changes in re-epithelialization, suggesting that dermal TGF$\beta$ signaling influences epidermal behavior during wound repair [92, 102]. For example, Denton et al. [102] and Martinez-Ferrer et al. [92] both observed increased keratinocyte proliferation in fibroblast-specific TGF- $\beta$ RII knockout wounds, and Martinez-Ferrer et al. [92] also reported a hypertrophic epidermis with increased keratin 5 expression. While one study showed a faster rate of re-epithelialization in fibroblast-specific TGF-RII knockout wounds during the early phase of healing [92], another found that the two groups of mice exhibited similar epithelial closure by the proliferative phase of healing [102]. These data support the concept that there is crosstalk between the two skin compartments during wound repair, and suggests that TGF- $\beta$ signaling in fibroblasts may normally exert some inhibitory effects on keratinocyte behavior during healing.

While TGF- $\beta 1$ stimulates the fibrotic effects necessary for dermal healing, excessive TGF- $\beta 1$ activity can lead to the formation of hypertrophic scars, in part through mechanisms mediated by $\beta$-catenin $[53,65]$ or $\mathrm{CCN} 2$ [110]. Indeed, TGF- $\beta 1$ signaling has long been noted for its 
association with inflammation and fibrosis following injury. One of the differences between adult and scarless fetal wound healing is the near absence of TGF- $\beta 1$ in the early fetal repair process $[4,111]$. The scar-promoting effects of TGF- $\beta 1$ are exemplified by the scarring reminiscent of adult wound repair caused by the application of TGF- $\beta 1$ to embryonic skin wounds [111]. In fact, scar-free embryonic wounds in rats have lower TGF- $\beta 1$ and higher TGF- $\beta 3$ levels than the scar-forming adult-like wounds that occur in late gestation [6]. The effects of hypoxia on TGF- $\beta 3$ $[112,113]$ may account for the increased TGF- $\beta 3$ levels in fetal versus adult healing. The application of TGF- $\beta 3$ has been shown to reduce scarring in a rodent wound model [86], although some reports dispute the antiscarring abilities of this molecule [114]. TGF- $\beta 3$ has been reported to reduce scar formation through effects on matrix production, cell movement and inflammatory mediators [115]. However, the precise molecular mechanisms involved are not clear. One possibility is raised by the finding that human serum (which contains TGF- $\beta 3$ ) promotes epithelial migration, while plasma (which does not contain detectable TGF- $\beta 3$ ) encourages dermal fibroblast migration [116]. It was suggested that the transition between these media (and thus exposure to soluble TGF- $\beta 3$ ) during wound healing influences the motility of different cell types [116]. It is conceivable that a related mechanism might operate during fetal wound healing to differentially influence the behavior of cells in different skin compartments exposed to TGF- $\beta 3$. However, research also suggests that the ability of fetal wounds to heal without scarring is an inherent property that does not depend on the fluid environment of the embryo $[9,117]$. The detailed mechanisms whereby TGF- $\beta 3$ may exert antiscarring actions await further investigation. Furthermore, as noted above, whether TGF- $\beta 3$ can act as a potential antiscarring agent is controversial. While a pharmaceutical formulation of TGF- $\beta 3$ has shown promise in improving the appearance of scars in phase II clinical trials [118], the drug did not meet some of the expected endpoints in phase III clinical trials [119].

Different components of the TGF- $\beta$ signaling pathway seem to be important in skin development and in postnatal wound repair. For example, while TGF- $\beta 1$ is a crucial component of the fibrogenic aspect of postnatal healing, it does not appear to play a significant role during embryonic skin morphogenesis. In contrast, other TGF- $\beta$ signaling molecules or mediators, such as TGF- $\beta 2$, participate in mediating certain aspects of skin development, such as hair follicle formation [78, 84].

Notch pathway

The Notch signaling pathway is a regulator of epidermal differentiation, both in the maintenance of skin homeostasis in the adult, and in embryonic development of the epidermis [26, 120, 121]. It also plays a major role in other developmental and physiological processes, including angiogenesis and vascular maintenance [122]. Notch is known to engage in crosstalk with the $\mathrm{Wnt} / \beta$-catenin and Hedgehog pathways [120], two other signaling pathways that participate in skin development and homeostasis. Notch signaling requires an interaction between a transmembrane ligand and the transmembrane Notch receptor on two adjacent cells [120-122]. In mammals there are four Notch receptors, and their ligands are members of the Delta-like and Jagged families [120-122]. Ligand binding causes sequential proteolytic cleavage of the Notch receptor, resulting in the liberation of the Notch intracellular domain (NCID) from the cell membrane and its translocation to the nucleus where it associates with RBP-J and other cofactors to modulate the transcription of target genes such as the Hes/Hey transcriptional repressors [120-122].

During skin development, Notch signaling regulates epidermal differentiation to ensure correct stratification of the epidermis [26, 123, 124]. Interestingly, cilia are involved in stimulating the Notch pathway during epidermal development, as demonstrated by the finding that mice lacking epidermal cilia show attenuated Notch signaling and impaired epidermal differentiation [125]. Some components and/or modulators of Notch signaling are expressed during development of dermal portions of the skin: Delta1 [126, 127] and Lunatic Fringe [127] are expressed in dermal condensates [126, 127], while Notch2 has been identified in the adjacent mesenchyme [127].

Research has suggested that the Notch pathway participates in wound repair, and that it is required for proper healing. Thelu et al. [128] described expression of Jagged1 and Notch1, as well as the signaling modulator, Lunatic Fringe, in healing epidermis of wounded human skin grafted onto mice [128]. Later studies examined the role of the Notch pathway during wound repair. Transgenic mice expressing a Notch antisense sequence that causes a $50 \%$ reduction in Notch protein, exhibited delayed healing as assessed by surface wound size [129]. Mice treated with the Notch ligand, Jagged, show accelerated wound closure (as assessed by surface wound size) suggesting that these effects are mediated by the Notch pathway [129]. In vitro scratch wound assays with cultured cells, using a Notch inhibitor or activator, suggest that part of the mechanism may involve promigratory effects of Notch on fibroblast and vascular endothelial cells [129]. In turn, Outtz et al. [130] found that Notch1 hemizygous (heterozygous) mice exhibit increased collagen deposition and vascularity in healing wounds. The participation of Notch signaling in angiogenesis during wound repair was also suggested by Caiado et al. [131] following in vitro studies where the Notch pathway regulated the matrix-adhering and 
angiogenic properties of bone marrow-derived vascular precursor cells. Injection of such cells into mice caused a reduction in the size of healing wounds and also increased the density of wound microvessels, whereas mice that were injected with cells treated with a Notch inhibitor did not exhibit these effects [131].

Interestingly, a potential role for Notch signaling in the wound inflammatory response, a process that does not exist during development, has recently been elucidated. Outtz et al. [130] utilized Notch1 hemizygous (heterozygous) mice, as well as mice with a myeloid-specific deletion of Notch1, to study the genetic effects of Notch1 deficiency on macrophage function during wound repair. Both mouse models exhibited reductions in macrophage recruitment and in the expression of various inflammatory cytokines and growth factors commonly secreted by macrophages [130]. The data suggest a role for Notch in regulating macrophage behavior during the inflammatory phase of healing [130]. In particular, in vitro and in vivo studies showed that Notch1 can modulate VEGF1 expression by macrophages [130]. Interestingly, wounds from mice with a myeloid-specific deletion of Notch1 did not show changes in the wound phenotype in terms of collagen deposition or the number of blood vessels, in contrast to mice with a general Notch $1+/-$ deletion, where these parameters were increased [130]. This suggested that cells other than macrophages are involved in mediating some of the effects of Notch1 on the wound phenotype [130].

There is evidence that the Notch pathway participates in wound repair, and that it may be involved in several aspects of healing, such as angiogenesis, matrix production, and inflammation. However, the role of Notch signaling in wound healing has not been as extensively studied as have some other pathways, and there are still many questions to explore. Some of the suggested roles for Notch signaling in healing are quite different from its function in skin development. For example, Notch's involvement in macrophage behavior during the inflammatory phase of wound repair is unique in the sense that this function would not be utilized during embryonic development. In addition, Notch is well known as a regulator of epidermal differentiation of skin $[26,120,121]$, but its role in this process during the re-epithelialization of healing wounds is relatively unexplored. In keeping with this, any influence of Notch on the behavior of various cell types, such as keratinocytes and fibroblasts, during healing must also be investigated. Thus, there are many interesting avenues of potential future research with regard to the involvement of Notch signaling in cutaneous wound repair.

Hedgehog pathway

The Hedgehog signaling pathway is involved in many aspects of embryonic development, including skin morphogenesis and angiogenesis [132, 133]. In skin development, it plays a significant role in the development of hair follicles and associated structures such sebaceous glands and the dermal papilla, as well as in the regulation of hair follicle and epidermal stem cells in the adult [46, 132, 134-138]. Hedgehog, Wnt/ $\beta$-catenin, and Notch signaling interact in many of these processes. Three Hedgehog proteins exist in mammals, termed Sonic Hedgehog (Shh), Desert Hedgehog (Dhh), and Indian Hedgehog (Ihh) [132, 139]. Here we focus on Shh signaling. Shh binds to the transmembrane protein and tumor suppressor, $\mathrm{PTCH}$, to de-repress the inhibition of Smoothened, resulting in activation of the Gli transcription factors and the regulation of downstream target genes [132, 139].

While the Shh pathway's involvement in skin development has been extensively studied, much less is known about its role in wound repair. Nevertheless, several recent studies have begun to address this issue and suggest that the Shh pathway may have the ability to modulate several aspects of wound healing, such as dermal repair, and wound vascularization [140, 141]. Shh is present in regenerated hair follicles following wound healing [7], but it is not expressed at detectable levels in wound epidermis or in the keratinocytes that contribute to re-epithelialization [142]. A study that used a reporter mouse expressing LacZ upstream of Ptcl to examine Shh pathway activation in murine wounds, found Patch1 expression in hair follicles close to the wound site and in the dermis adjacent to the hair follicles [140]. The authors then tested the effects of Shh on wound repair in diabetic mice using methylcellulose pellets that contained a human Shh-expressing plasmid. Topical application of the plasmid to mouse wounds stimulated Shh expression in keratinocyte-like and fibroblast-like cells [140]. Interestingly, diabetic mice treated with Shh exhibited improvements in re-epithelialization and dermal healing, including a larger and more collagen-rich dermal compartment, compared to control mice [140]. The wounds of Shh-treated mice also exhibited increased cellularity and vascularity [140]. The 'fibrotic' effects observed in Shh-treated wounds may be caused by enhanced fibroblast activity, as Shh stimulated proliferation of primary dermal fibroblasts in vitro [140]. Further, it was found that Shh treatment increases both VEGF expression and the recruitment of bone marrow-derived endothelial progenitor cells to wound vasculature, suggesting a possible mechanism for the increased vascularity in Shh-treated wounds [140]. Complimentary to these results, in a more recent study, mice treated with the Shh inhibitor cyclopamine for 30 days after wounding showed delayed wound closure and reduced dermal granulation tissue formation [141]. In addition, wound vascularity and cell proliferation were adversely affected in response to Shh inhibition [141]. Another study also found activation of the Shh pathway in 
Table 3 Contribution of developmental signaling pathways to tissue healing (regeneration) in selected nonmammalian species

\begin{tabular}{|c|c|c|c|c|}
\hline Animal group & $\mathrm{Wnt} / \beta$-catenin & TGF- $\beta$ & Notch & Hedgehog \\
\hline Planarians & Tail regeneration & & & Tail regeneration \\
\hline Fly & Dorsal closure & Dorsal closure & & \\
\hline Fish & Blastema formation & & & Fin regeneration \\
\hline Amphibians & Tail regeneration, limb regeneration & Tail regeneration & Tail regeneration & Tail regeneration \\
\hline
\end{tabular}

Empty cells indicate that there are no conclusive studies that support involvement of the indicated signaling pathway

murine cutaneous wounds, and treatment of diabetic mice with topical Shh improved healing by modulating the nitric oxide pathway [143].

Thus Shh has the potential to influence several aspects of wound healing, including dermal tissue repair and vascularization. Additional studies are required to elucidate the mechanisms behind some of these effects and to define the physiological role of Shh in wound repair more precisely, including its function(s) in different cell types. One area of interest would be to determine whether Shh signaling is a participant in epithelial-mesenchymal interactions during wound repair. Importantly, future research on Shh in wound repair should be undertaken using appropriate genetically modified mouse models to compliment the largely pharmacological studies in this area to date. Thus, while the role of Shh in wound repair is a relatively unexplored topic compared to its role in skin development, the evidence suggests that this is a promising area of future research.

\section{Wound healing across the taxa}

All organisms are exposed to environmental cues around them. For a long life, multicellular organisms must maintain their tissue morphology and its function. The environment is riddled with potential sources of harmfrom sharp surfaces to infectious organisms searching for routes to penetrate an organism's body armor. To deal with these threats, multicellular organisms are equipped with a strong waterproof barrier that protects them from physical harm. All multicellular organisms are able to respond to injury and repair their tissue to some extent. For example, upon epidermal injury, a conserved innate immune system functions in both vertebrates and invertebrates [144] to combat infectious microbes. In order to preserve tissue integrity, it is essential that organisms detect the loss of tissue mass, activate the de novo production of cells, and organize those cells into functional tissues. However, there is huge diversity in how the process of healing occurs across the taxa. Some multicellular organisms can regenerate the missing part of the body while others cannot. In spite of this diversity, there are basic principles of healing shared by many multicellular organisms: injury detection, gap closure, cell division activation to supply new cells, cell differentiation, and remodeling of newly formed tissue. Even the earliest branching animals (e.g. the sponge Oscarella carmela) express core components of the Wnt, TGF- $\beta$, Notch and Hedgehog signaling pathways [145]. In mammals, despite considerable ability for tissue regeneration, large wounds result in the formation of scar tissue instead of a complete restoration of tissue morphology and function [5]. This limited regenerative capacity is partly due to rapid interposition of fibrotic tissue, something that prevents subsequent tissue regeneration, but might be a defensive advantage in preventing harmful microbes [5]. Tissue regeneration in humans, however, is very limited. If injured, only bone, liver and infant finger tips can regenerate [70, 146, 147]. Aging is another determinant for tissue restoration, as animals gradually lose their regenerative capacity as they get older. The diversity in tissue restoration is due to the species, the type of injured tissue, and the age of the animal. It seems that during vertebrate evolution, some of the regenerative ability of lower multicellular organisms was inactivated.

As noted, core components of the Wnt, TGF- $\beta$, Notch and Hedgehog signaling pathways are expressed in sponges and higher organisms across the taxa [145]. Preservation of signaling pathways across taxa requires a universal way by which multicellular organisms respond to injury and heal their bodies. If we are able to unveil the mechanism of tissue preservation across the taxa, we may open new doors for tissue/organ regeneration in humans, preferably by enhancing our endogenous ability which was inactivated during evolution. A clue may come from the following nonmammalian species that have an impressive ability to regenerate (Table 3 ).

\section{Planarians}

Planarians are a group of nonparasitic flatworms. They lack complex organs but can fully regenerate [148]. A planarian split lengthwise or crosswise will regenerate into two separate individuals. Planarian regeneration involves changes in preexisting tissues and the formation of an outgrowth. It starts with the formation of a mass of proliferating cells (blastema) at the site of injury. Blastema cells become organized into tissue and regenerate organ systems [148]. 
Small fragments of tissue (as little as 1 part in 289) [5] can regenerate into entire new animals, including all components of the body. When a planarian is cut transversely, the caudal fragment will regenerate a head and the anterior piece will regenerate a tail. It is has been shown that after injury, Wnt signaling promotes tail regeneration. In the head-versus-tail regeneration experiment, Wnt inhibitor notum preferentially expresses at anterior-facing wounds [149], highlighting the essential role of Wnt signaling during planarian regeneration. Planarians depleted of WntP-1 regenerate a head in place of a tail [150]. On the other hand, Hedgehog signaling induces regeneration of a tail instead of a head through the activation of Wnt transcription [151, 152]. This suggests the importance of Wnt/ $\beta$-catenin and Hedgehog pathways for anteroposterior axis specification during regeneration.

\section{Fly}

Mammalian skin and insect cuticle form a protective barrier that helps prevent dehydration and protect against injury. In the fruit fly Drosophila, this barrier has a singlecell layer of epidermal cells that secrete cuticle. This cuticle is equivalent to the stratum corneum in mammalian skin, which consists of dead squamous epithelial cells.

Developments in genetic manipulation have allowed the study of wound healing signaling pathways in fruit flies which may provide new insights into biological processes, including wound healing, in humans. Despite differences in the molecular composition of insect cuticle and mammalian skin, it is noteworthy that some regulatory mechanisms for the development and healing of protective barriers in insects and mammals have been conserved. For instance, a master gene called grainy head (grh) activates wound repair genes in the cells surrounding an injury in the cuticle of fly embryos [153]. These wound repair genes then regenerate the injured patch of cuticle. Wounds in mutant flies that lack the grh gene fail to heal. Interestingly, the grh gene is also essential for normal skin development and wound repair in mice. Like their fruit fly counterparts, mice lacking grh have a much more permeable skin than normal mice, and also have deficient wound repair [154]. These two studies signify an imperative concept in wound healing: although the structure of the surface barrier is considerably different across taxa, the signaling pathways that coordinate healing of the barrier are evolutionarily conserved.

Morphological events such as dorsal closure [155] and tracheal fusion [156] during Drosophila melanogaster development, have notable similarity to wound repair in humans. Dorsal closure of the Drosophila embryo is the best-characterized example of epithelial sheet movement leading to epithelial fusion. It involves migration of the lateral epidermal flanks to close a hole in the dorsal epidermis occupied by an epithelium [157]. Morphogenetic events involving tissue migration and epithelial fusion have been used as models to examine the involvement of developmental signaling pathways in wound repair. Wnt/ Wingless (Wg) signaling has been shown to play an essential role during dorsal closure [158]. Moreover, the TGF- $\beta$ signaling pathway is required for dorsal closure, and acts downstream of the JNK cascade [159, 160]. These signaling pathways regulate cytoskeletal reorganization and cell shape change to orchestrate cell migration for dorsal closure.

\section{Fish}

In some of the fish species, when a major part of the fin, or even the entire fin, is removed, it is regenerated with recovery of its shape and function [161]. Fish fins have been used for analyzing the regeneration process for more than two centuries [162]. Caudal fin regeneration is dependent on the presence of musculature and endoskeleton at the site of amputation [161]. A layer of epidermal cells covers the fin rays and the mesenchymal tissue around them. Immediately after injury, an F-actin purse string is formed in the epithelial cells surrounding the wound gap and quickly contracts to close the epithelial opening [14]. Later, the epithelial cells migrate to make a tight epithelial sealing on the wound gap. Wound closure is complete by this stage. The process of cell proliferation starts and forms a new epidermis (called wound epidermis) to cover the wounded area. As in their mammal counterparts, this epidermis layer is distinguishable from the surrounding epidermis by its thick morphology [163]. Following the formation of the wound epidermis, a mass of proliferating mesenchymal cells forms (again called blastema). The blastema (which is in close contact with the wound epidermis) continues to proliferate until an adequate cell supply is available to replace the lost part. In order to study the developmental signaling pathways involved in healing, different genetic methods or specific biochemical assays have been used. Here, we discuss the role of some of the above-mentioned signaling pathways during the fish healing process.

Amputating the caudal fin in zebrafish stimulates regeneration of the dermal skeleton and re-expression of Shh signaling pathway genes. The essential role of Hedgehog signaling in bone differentiation in the fin-ray has been demonstrated [164] using cyclopamine (an inhibitor of Hedgehog signaling). Exposure to cyclopamine alters bone patterning. FGF receptor 1 (FGFR1) is expressed in mesenchymal cells underlying the wound epidermis during blastema formation and in distal blastemal tissue during regenerative outgrowth. Using SU5402 (an inhibitor 
of FGF signaling), blastemal cell proliferation is blocked, leading to the prevention of outgrowth during ongoing fin regeneration [165]. This shows the necessity of FGF signaling for zebrafish fin blastema formation and regenerative outgrowth. It is interesting to note that the $\mathrm{Wnt} / \beta$-catenin signaling acts upstream of FGF signaling [166]. The importance of $\mathrm{Wnt} / \beta$-catenin signaling has been shown using transgenic fish lines. During zebrafish tail fin regeneration, $\mathrm{Wnt} / \beta$-catenin signaling is activated and is required for the formation, and subsequent proliferation, of the blastema progenitor cells [166]. Using a dominant-negative form of $\mathrm{T}$ cell factor (to transcriptionally block $\mathrm{Wnt} / \beta$ catenin signaling) or DKK1 (to block Wnt/ $\beta$-catenin signaling at the ligand level), this essential role of the Wnt signaling pathway was highlighted [166]. Furthermore, MMP inhibitors also inhibit the regeneration process and result in reduced cell proliferation in the blastema [167]. Studies over the last few decades have shown the critical role of some of these developmental signaling pathways during fish regeneration and have advanced our understanding of how activation of these pathways in a timely manner leads to tail fin regeneration.

\section{Amphibians}

Some species of amphibians, a class of vertebrates including frogs and salamanders, have the ability to regenerate amputated appendages through the formation of a blastema. While the origin of blastema cells is unclear, in urodeles, it has been suggested that the blastema is formed by the de-differentiation of nearby cells [168, 169]. This highlights the existence of plastic residual differentiated cells rather than the existence of so-called "reserve stem cells" [170]. However, using a lineage-tracing approach in the salamander, each tissue produces progenitor cells with restricted potential [171]. While this challenges the existence of a unique cell with multipotential regenerative capacity, it nonetheless reveals the fabulous endogenous regenerative machinery that is partly inactivated in humans. Adult urodele amphibians can restore limbs, tails, the lens and retina of the eyes, and heart tissue [172]. This remarkable ability, together with the close relationship between amphibians and mammals, makes amphibians a very attractive model for the study of regeneration.

The importance of several developmental signaling pathways has been shown in recent studies on Xenopus. Wnt signaling inhibition using DKK1 at the beginning of regeneration is sufficient to efficiently inhibit both tail and limb regeneration in Xenopus [173]. Likewise, using BIO (a cell-permeable compound that acts as a highly potent ATP-competitive inhibitor of GSK-3 $\alpha / \beta$ [174]) as an enhancer for the $\mathrm{Wnt} / \beta$-catenin signaling pathway causes blastema cell proliferation to increase and leads to enhanced outgrowth of the regenerating tail [175]. Notch signaling is also necessary for tail regeneration in Xenopus. Blocking Notch signaling with the protease inhibitor MG132 (which inhibits the cleavage of the NCID) blocks tail regeneration [176], suggesting involvement of the Notch signaling pathway in tail regeneration. However, considering the nonselective effect of this protease inhibitor, the specific targeting of the Notch pathway using this compound remains to be defined.

In Xenopus, the notochord provides a source of Shh to the cells near the amputation site. Therefore, it is conceivable that the availability of Shh in the stump tissues determines the regenerative potential of each amputated site. In support of this, treatment with cyclopamine (the Shh signaling inhibitor) has been shown to prevent tail regeneration in urodeles [177]. However, unlike tail regeneration, cyclopamine-treated regenerating limbs attain a normal length and contain cartilage [177]. This shows that temporal and spatial expression of morphogens during development may give a clue as to which developmental signaling pathway plays the crucial role for the regeneration of each organ. TGF- $\beta$ signaling has been shown to play a vital role in wound healing of the tail [178]. Amputated animal tails that are treated immediately and continuously with SB431542 (a TGF- $\beta$-specific inhibitor) fail to form a wound epidermis and tail regeneration is blocked [178].

Unlike most amphibians which undergo metamorphosis (from egg to larva and larva to adult form), in a condition called neoteny, the axolotl continues to show larval features throughout its life, retaining external gills and with undeveloped limbs [179]. These paedomorphic axolotls are fully aquatic, sexually mature and fail to completely metamorphose. Moreover, they are capable of flawlessly repairing full-thickness excisional wounds made on their dorsal flank [179]. A study comparing skin regeneration between paedomorphic and metamorphic axolotls (by induction of metamorphosis in adult axolotls) has shown that aquatic (paedomorphic) axolotls re-epithelialize faster, have fewer leukocytes during early inflammation, have less ECM deposition and a faster regeneration (two times faster for complete skin regeneration) [180]. This highlights the relationship between retention of larval characteristics (i.e. paedomorphic axolotls) with the process of regeneration (faster regeneration) as observed in other vertebrates [181]. However, the fact that both paedomorphic and metamorphic axolotls are capable of scar-free healing (with a delay in metamorphic axolotls) implies that ultimately both paedomorphic and metamorphic axolotls are able to revert to the earlier stage of development to regenerate, suggesting an intrinsic capability in cells regardless of their larval stage. Unraveling this intrinsic capability might be the key for scarless skin healing and complete regeneration in humans. 


\section{Clinical aspects of wound healing in humans: perspective}

The human skin forms a large physical barrier between the body and its environment. Skin diseases can have many mental and physical effects on the quality and length of life [182]. Likewise, deficient wound healing may impose huge mental and physical burdens on patients. It has been reported that about $15 \%$ of older adults suffer from chronic wounds [183]. Furthermore, every 30 seconds, a lower limb is lost somewhere in the world as result of wound infection [183]. This not only affects the personal life of the individual, but also has a huge economic effect on society. The burden of treating wounds with deficient healing is growing rapidly due to escalating health-care costs, aging populations, and a sharp increase worldwide in the incidence of diseases such as diabetes. In the US alone, the collective health-care cost of chronic wounds is estimated at $\$ 25$ billion annually [184]. The annual wound care products market reached $\$ 15$ billion in 2010 [183]. These factors all impose a great cost on society, and emphasize the necessity for better management of deficient wound healing. One strategy is to develop therapies that manipulate the developmental signaling pathways discussed above in an attempt to recapitulate wound repair observed during fetal healing and the process of regeneration.

While some wound healing complications are due to delayed healing, occurring in patients with diabetes, immunodeficiency, or radiation exposure, some complications are also due to excessive healing, such as hypertrophic and keloid scarring [5]. Such scarring causes morbidity, particularly when the scar is close to a vital organ or if it limits the motion of a joint. Hypertrophic scars mainly occur after major injuries such as burns, leading to poorly structured skin with cosmetic and medical consequences. On the other hand, keloid scars are tough, heaped-up scars that rise quite suddenly above the skin for unknown reasons after a minor injury. They tend to enlarge progressively and occur with a familial tendency [185]. Some keloids arise from a mature scar some years after the initiating events [185]. Several studies have investigated the contribution of molecules in the SMADdependent TGF- $\beta$ signaling pathways at both the mRNA and protein levels in keloids [186-189]. It is intriguing that TGF- $\beta$ has been shown to upregulate the $\mathrm{Wnt} / \beta$-catenin pathway in hypertrophic scars and keloids [53, 56, 61]. Moreover, in skin organotypic culture, R-spondin2 (a secreted protein known to be a $\mathrm{Wnt} / \beta$-catenin signaling agonist [190]) thickens the epidermis, a hyperproliferative phenotype observed in keloids [191]. These studies suggest a role for $\mathrm{Wnt} / \beta$-catenin signaling in the pathogenesis of keloids. Although no direct involvement of the Hedgehog and Notch signaling pathways in keloid pathogenesis has been suggested, Gli-1 has been shown to be upregulated in keloids [192].

For decades, growth factors were the main focus of research. Several studies have tried to identify the role of growth factors during skin healing, mainly considering wound healing enhancers [193, 194]. This has made growth factors the core of the therapeutic approach for disturbed healing, which has in turn led to several double-blind trials using different growth factors in humans. Some of these trials have shown promising preliminary results, but none of the growth factors has been approved for clinical use [14, 15, 195-197]. A correlation exists between increased amounts of TGF- $\beta$ and fibroblast hyperproliferation during hypertrophic scarring [66, 198, 199]. On this basis, clinical studies were designed to decrease scar formation using antibodies or molecules directed against TGF- $\beta$ [200]. For example, early work investigating the application of exogenous TGF- $\beta 2$ to venous stasis ulcers was promising [201]. Recently, a phase II clinical trial study showed that intradermal TGF- $\beta 3$ administration following scar revision surgery significantly improved scar appearance compared with a placebo [202]. However as noted, it did not meet the expected endpoints in phase III clinical trials [119]. A TGF- $\beta$ antagonist increased the speed of re-epithelialization and reduced scar formation and wound contraction in a partial thickness burn experiment in pigs [105]. While the recent trend seems promising, multiple well-designed clinical trials will be indispensable to evaluating the efficiency of TGF- $\beta$ components for the management of deficient wounds. This is because multiple clinical trials have failed to show the efficiency of TGF- $\beta$ in the treatment of chronic wounds [76].

To date, only human recombinant PDGF-BB has received FDA approval for the management of limb diabetic ulcers [203], and ulcers treated with PDGF-BB showed only a $15 \%$ greater healing incidence compared to placebo-treated ulcers [203-205]. Moreover, in 2008 the FDA warned of an increased risk of cancer mortality in patients who need extensive treatment with PDGF-BB. There are also some reports on the anti-scarring effects of FGF-2, including in clinical use [206]. Postoperative administration of FGF-2 inhibits hypertrophy and widening of scars without any serious side effects. Indeed, in Japan, FGF-2 is already used clinically. Moreover, there are some reports which highlight the clinical advantage of using EGF during recovery from life-threatening conditions [207].

In spite of all these advances, these approaches have not led to substantial changes in patient care. It is likely that limited success in single-factor therapies is due to their off-target effects, the difficulty in correctly timing their administration during healing, and the dynamic nature of the wound healing process. In addition, the interactions among growth factors, their receptors, and other ECM 
components are also critical for the clinical delivery of growth factors. Studies in a diabetic mouse model of chronic wounds have shown that an engineered form of recombinant fibronectin greatly enhances the regenerative effects of administered growth factors [208]. This suggests that combination therapy may tackle some barriers in the management of disturbed wound healing. An alternative approach to wound management would be to use cells that contribute to normal healing. Providing the cells whose contribution in normal wound healing is known together with the correct microenvironmental elements that are important for these cells to thrive, could be a feasible alternative approach in the management of deficient skin healing. Therefore, finding the origin of cells that contribute to normal skin wound healing may open new doors to candidate cell therapy sources, and these cells could potentially be sources of growth factors as well [60].

Approaches that are currently available to optimize wound repair include refinements in surgical technique, nutritional supplementation, and the use of local wound care modalities [209]. Despite these approaches, there has been little progress in the ability to regulate wound size. Surgical advances have helped minimize deficient skin healing following surgery, but scar formation is still just a minimal cost of surgery. Laser technology has evolved over the past few decades and may be useful in the treatment of select scars [210, 211]. However, more research is needed with less bias, better-defined laser settings, better outcome measurement characteristics, and standardized measuring methods to evaluate outcomes in humans. Animal models and in vitro experiments have also shown that lasers can facilitate rapid resolution of cutaneous ulceration, although this has yet to be consistently observed in humans.

The laser was first used as a surgical tool shortly after its invention as an alternative to mechanical surgical tools [212]. As a cutting modality, lasers can perform surgery at the fundamental limit by exploiting the spatial phase coherence of laser radiation to focus sufficient intensity for ablation or cutting at the single cell level. A recent study has shown that, in mouse wound healing, a new laser is able to ablate tissue at the single cell level [69]. Of particular note, the smaller scar size in tissue ablation is accompanied by less $\mathrm{Wnt} / \beta$-catenin and TGF $\beta$ signaling pathway activation [69]. This tackles part of the problem that exists with thermal lasers [213].

Despite all these advances, the ultimate standard for management of deficient skin healing is to prove the relevance of animal wound healing research to humans. Effective therapeutic and preventive strategies depend on our understanding of wound healing, the biology of scar formation, and the cells that contribute to the healing process. This may be achieved by elucidating the molecular pathways whereby adult cutaneous healing differs from embryonic skin development and regeneration. The ultimate goals should be the transformation of fibrotic events into regenerative events in the case of over-scarring, as well as the provision of cells (and cell niche) to regenerate in the case of non-healing. Studying the developmental signaling pathways that are essential for wound healing and manipulating them at the right time during the course of wound healing may be a strategy for tackling some complications. The vast social and economic impact of disturbed wound healing calls for the allocation of more resources to identify biological mechanisms underlying the complexities of wound healing.

\section{Conclusions and future directions}

Here we have discussed the roles of several key developmental signaling pathways (Wnt $/ \beta$-catenin, TGF- $\beta$, Notch, Hedgehog) in mammalian cutaneous wound repair and compared them with their functions in embryonic skin development and regeneration. The Wnt/ $\beta$-catenin, Notch, Hedgehog and TGF- $\beta$ families are well characterized as major regulators of developmental processes. The TGF- $\beta$ pathway in turn is infamous as a mediator of cutaneous healing. Because of the parallels between skin healing and embryonic skin development, a review of the research concerning the roles of these developmental signaling pathways in cutaneous wound repair has the potential to generate new perspectives for these events. Although both skin repair and development are designed to construct skin, they have very different outcomes in mammals. The properties of the scar tissue produced by cutaneous wound repair differ substantially from the skin we are born with. Insights into the relationship between skin repair and development may be harnessed to generate new therapies for treating wound healing disorders. Similarly, understanding the signaling events that regulate healing in species with the ability to completely regenerate their damaged tissue may suggest strategies for improving wound healing outcomes in humans. To achieve these goals, future research should aim to elucidate the mechanisms which differentiate mammalian skin repair from skin development and regeneration.

The inflammatory response constitutes one of the key differences between cutaneous wound repair and embryonic skin development in mammals. While the inflammatory response is crucial to protect the organism from infection and further harm, it is also a major factor in the pathogenesis of scar formation. As discussed above, the actions of inflammatory cells and their cytokines released during wound repair contribute to fibrosis and the formation of scar tissue. The aim of clinical therapies should be to achieve an optimal balance between the protective function 
of inflammation and the prevention of excessive scar tissue formation. This may be achieved by enhancing our understanding of how and when developmental and other signaling pathways interact during inflammation and in the transition to the proliferative phase of healing. For example, some growth factors and ECM components are present at different concentrations in scar-less fetal repair versus adult healing $[4,6,9]$. Further insight into the mechanisms that regulate the transition in the wound milieu between the fetus and adult may allow manipulation of signaling mediators to mimic the embryonic environment.

In general, the developmental signaling pathways discussed here have been more extensively investigated in the context of developmental biology than in wound repair. However, it is clear that many of these pathways play parallel or similar roles in both processes. As these signaling pathways are involved in complex epithelialmesenchymal crosstalk during development, it is imperative to further investigate such interactions between different cellular compartments during cutaneous wound healing. Related to this is the concept of crosstalk between cells and their microenvironment or niche [16], a subject of intense interest, particularly in the fields of developmental biology, stem cell, and cancer research. As a recent example from our laboratory shows in terms of the influence of fibronectin on fibroblast behavior [62], these interactions also take place during wound repair. Directions for future research thus include further investigating crosstalk between different cell types (including skin stem cells) and compartments, and between cells and the ECM, during the wound repair process. The wound is a dynamic environment and achieving a complete understanding of the nature of these relationships, which may occasionally be fluid or transient, is certainly a challenging task. However, it is also an important area of investigation if we are to fully understand the mechanisms that regulate skin repair and those that regulate development.

Finally, while we have discussed only a few key developmental signaling pathways in this review, a multitude of other signaling mediators participate in wound repair, development, and regeneration, some of which may not yet have been identified. Insight into the identities of the molecules and pathways that may account for differences between postnatal and fetal healing has been aided by high-throughput approaches, such as expression array analysis [214, 215]. Although gene expression studies are valuable in identifying candidates, they should be combined with proteomics approaches to uncover possible variations in protein synthesis or modification between subjects. The role of microRNAs in regulating wound repair [216] is another emerging topic of exploration that may elucidate some of the regulators in adult and fetal healing. While such mass-throughput approaches certainly represent a valuable means of filtering information and identifying possible targets for further analysis, it is important that the interactions of candidate molecules and signaling pathways be validated in vivo. The complex and dynamic wound environment cannot be completely recapitulated in vitro, but can be most thoroughly examined in its natural in vivo setting where all of the required factors, both known and unknown, are present.

The intricate and dynamic nature of the wound environment suggests that successful therapies for treating wound healing disorders will not rely upon a single allencompassing agent, but will likely require a multitude of factors administered at different periods during the wound healing process. Identifying the relationships between developmental signaling pathways in adult wound repair and fetal skin development and/or regeneration will certainly propel the research community closer to this goal, and is a fruitful area of future investigation.

Acknowledgments Grant Support: This work was supported by a grant from the Canadian Institutes of Health Research FRN 15136. S Amini-Nik is partly supported by Ontario Institute for Cancer Research, B.A. Alman is supported by the Canada Research Chairs Programme. We thank Bonnie Tang for preparing the illustration in Fig. 1. We apologize to the many investigators whose work we could not cite due to limited space.

Open Access This article is distributed under the terms of the Creative Commons Attribution License which permits any use, distribution, and reproduction in any medium, provided the original author(s) and the source are credited.

\section{References}

1. Yamada KM, Clark RAF (1996) Provisional matrix. In: Clark RAF (ed) The molecular and cellular biology of wound repair, 2nd edn. Plenum Press, New York, pp 51-82

2. Ffrench-Constant C, Van de Water L, Dvorak HF, Hynes RO (1989) Reappearance of an embryonic pattern of fibronectin splicing during wound healing in the adult rat. $\mathrm{J}$ Cell Biol 109(2):903-914

3. Clark RAF (1996) Wound repair: overview and general considerations. In: Clark RAF (ed) The molecular and cellular biology of wound repair, 2nd edn. Plenum Press, New York, pp 3-35

4. McCallion RL, Ferguson MWJ (1996) Fetal wound healing and the development of antiscarring therapies for adult wound healing. In: Clark RAF (ed) The molecular and cellular biology of wound repair, 2nd edn. Plenum Press, New York, pp 561-590

5. Gurtner GC, Werner S, Barrandon Y, Longaker MT (2008) Wound repair and regeneration. Nature 453(7193):314-321. doi: 10.1038/nature07039

6. Soo C, Beanes SR, Hu FY, Zhang X, Dang C, Chang G, Wang Y, Nishimura I, Freymiller E, Longaker MT, Lorenz HP, Ting K (2003) Ontogenetic transition in fetal wound transforming growth factor-beta regulation correlates with collagen organization. Am J Pathol 163(6):2459-2476

7. Ito M, Yang Z, Andl T, Cui C, Kim N, Millar SE, Cotsarelis G (2007) Wnt-dependent de novo hair follicle regeneration in adult 
mouse skin after wounding. Nature 447(7142):316-320. doi: 10.1038/nature05766

8. Dudas M, Wysocki A, Gelpi B, Tuan TL (2008) Memory encoded throughout our bodies: molecular and cellular basis of tissue regeneration. Pediatr Res 63(5):502-512. doi:10.1203/ PDR.0b013e31816a7453

9. Larson BJ, Longaker MT, Lorenz HP (2010) Scarless fetal wound healing: a basic science review. Plast Reconstr Surg 126(4):1172-1180. doi:10.1097/PRS.0b013e3181eae781

10. Verrecchia F, Mauviel A (2002) Control of connective tissue gene expression by TGF beta: role of Smad proteins in fibrosis. Curr Rheumatol Rep 4(2):143-149

11. Leask A, Abraham DJ (2004) TGF-beta signaling and the fibrotic response. FASEB J 18(7):816-827. doi:10.1096/fj.031273rev

12. Li-Korotky HS, Hebda PA, Lo CY, Dohar JE (2007) Agedependent differential expression of fibronectin variants in skin and airway mucosal wounds. Arch Otolaryngol Head Neck Surg 133(9):919-924. doi:10.1001/archotol.133.9.919

13. Coolen NA, Schouten KC, Middelkoop E, Ulrich MM (2010) Comparison between human fetal and adult skin. Arch Dermatol Res 302(1):47-55. doi:10.1007/s00403-009-0989-8

14. Martin P (1997) Wound healing-aiming for perfect skin regeneration. Science 276(5309):75-81

15. Singer AJ, Clark RA (1999) Cutaneous wound healing. N Engl J Med 341(10):738-746. doi:10.1056/NEJM199909023411006

16. Watt FM, Fujiwara H (2011) Cell-extracellular matrix interactions in normal and diseased skin. Cold Spring Harb Perspect Biol 3 (4). doi:10.1101/cshperspect.a005124

17. Schultz GS, Davidson JM, Kirsner RS, Bornstein P, Herman IM (2011) Dynamic reciprocity in the wound microenvironment. Wound Repair Regen 19(2):134-148. doi:10.1111/j.1524-475X. 2011.00673.x

18. Guo S, Dipietro LA (2010) Factors affecting wound healing. J Dent Res 89(3):219-229. doi:10.1177/0022034509359125

19. Mahdavian Delavary B, van der Veer WM, van Egmond M, Niessen FB, Beelen RH (2011) Macrophages in skin injury and repair. Immunobiology 216(7):753-762. doi:10.1016/j.imbio.2011. 01.001

20. Clark RA (1990) Fibronectin matrix deposition and fibronectin receptor expression in healing and normal skin. J Invest Dermatol 94(6 Suppl):128S-134S

21. Grinnell F, Toda K, Takashima A (1987) Activation of keratinocyte fibronectin receptor function during cutaneous wound healing. J Cell Sci Suppl 8:199-209

22. Moulin V, Auger FA, Garrel D, Germain L (2000) Role of wound healing myofibroblasts on re-epithelialization of human skin. Burns 26(1):3-12

23. O'Toole EA (2001) Extracellular matrix and keratinocyte migration. Clin Exp Dermatol 26(6):525-530

24. Watt FM, Jensen KB (2009) Epidermal stem cell diversity and quiescence. EMBO Mol Med 1(5):260-267. doi:10.1002/emmm. 200900033

25. Taylor G, Lehrer MS, Jensen PJ, Sun TT, Lavker RM (2000) Involvement of follicular stem cells in forming not only the follicle but also the epidermis. Cell 102(4):451-461

26. Blanpain C, Fuchs E (2009) Epidermal homeostasis: a balancing act of stem cells in the skin. Nat Rev Mol Cell Biol 10(3):207-217. doi:10.1038/nrm2636

27. Ito M, Liu Y, Yang Z, Nguyen J, Liang F, Morris RJ, Cotsarelis G (2005) Stem cells in the hair follicle bulge contribute to wound repair but not to homeostasis of the epidermis. Nat Med 11(12):1351-1354. doi:10.1038/nm1328

28. Snippert HJ, Haegebarth A, Kasper M, Jaks V, van Es JH, Barker N, van de Wetering M, van den Born M, Begthel $\mathrm{H}$, Vries RG, Stange DE, Toftgard R, Clevers H (2010) Lgr6 marks stem cells in the hair follicle that generate all cell lineages of the skin. Science 327(5971):1385-1389. doi:10.1126/science.1184 733

29. Jensen KB, Collins CA, Nascimento E, Tan DW, Frye M, Itami S, Watt FM (2009) Lrig1 expression defines a distinct multipotent stem cell population in mammalian epidermis. Cell Stem Cell 4(5):427-439. doi:10.1016/j.stem.2009.04.014

30. Langton AK, Herrick SE, Headon DJ (2008) An extended epidermal response heals cutaneous wounds in the absence of a hair follicle stem cell contribution. J Invest Dermatol 128(5):13111318. doi:10.1038/sj.jid. 5701178

31. Darby I, Skalli O, Gabbiani G (1990) Alpha-smooth muscle actin is transiently expressed by myofibroblasts during experimental wound healing. Lab Invest 63(1):21-29

32. Hinz B (2007) Formation and function of the myofibroblast during tissue repair. J Invest Dermatol 127(3):526-537. doi: 10.1038/sj.jid.5700613

33. Desmouliere A, Redard M, Darby I, Gabbiani G (1995) Apoptosis mediates the decrease in cellularity during the transition between granulation tissue and scar. Am J Pathol 146(1):56-66

34. Nelson WJ, Nusse R (2004) Convergence of Wnt, beta-catenin, and cadherin pathways. Science 303(5663):1483-1487. doi: 10.1126/science. 1094291

35. Angers S, Moon RT (2009) Proximal events in Wnt signal transduction. Nat Rev Mol Cell Biol 10(7):468-477. doi:10.1038/ nrm2717

36. Archbold HC, Yang YX, Chen L, Cadigan KM (2012) How do they do Wnt they do? Regulation of transcription by the Wnt/ beta-catenin pathway. Acta Physiol (Oxf) 204(1):74-109. doi: 10.1111/j.1748-1716.2011.02293.x

37. Cadigan KM, Peifer M (2009) Wnt signaling from development to disease: insights from model systems. Cold Spring Harb Perspect Biol 1(2):a002881. doi:10.1101/cshperspect.a002881

38. Gao C, Chen YG (2010) Dishevelled: the hub of Wnt signaling. Cell Signal 22(5):717-727. doi:10.1016/j.cellsig.2009.11.021

39. Hehlgans S, Haase M, Cordes N (2007) Signalling via integrins: implications for cell survival and anticancer strategies. Biochim Biophys Acta 1775(1):163-180. doi:10.1016/j.bbcan.2006.09.001

40. Lilien J, Balsamo J (2005) The regulation of cadherin-mediated adhesion by tyrosine phosphorylation/dephosphorylation of betacatenin. Curr Opin Cell Biol 17(5):459-465. doi:10.1016/j.ceb. 2005.08.009

41. Widelitz RB (2008) Wnt signaling in skin organogenesis. Organogenesis 4(2):123-133

42. Yamaguchi Y, Hearing VJ, Itami S, Yoshikawa K, Katayama I (2005) Mesenchymal-epithelial interactions in the skin: aiming for site-specific tissue regeneration. J Dermatol Sci 40(1):1-9. doi:10.1016/j.jdermsci.2005.04.006

43. Atit R, Sgaier SK, Mohamed OA, Taketo MM, Dufort D, Joyner AL, Niswander L, Conlon RA (2006) Beta-catenin activation is necessary and sufficient to specify the dorsal dermal fate in the mouse. Dev Biol 296(1):164-176. doi:10.1016/j.ydbio.2006. 04.449

44. Ohtola J, Myers J, Akhtar-Zaidi B, Zuzindlak D, Sandesara P, Yeh K, Mackem S, Atit R (2008) beta-Catenin has sequential roles in the survival and specification of ventral dermis. Development 135(13):2321-2329. doi:10.1242/dev.021170

45. Driskell RR, Clavel C, Rendl M, Watt FM (2011) Hair follicle dermal papilla cells at a glance. J Cell Sci 124(Pt 8):1179-1182. doi: $10.1242 /$ jcs. 082446

46. Huelsken J, Vogel R, Erdmann B, Cotsarelis G, Birchmeier W (2001) beta-Catenin controls hair follicle morphogenesis and stem cell differentiation in the skin. Cell 105(4):533-545

47. Andl T, Reddy ST, Gaddapara T, Millar SE (2002) WNT signals are required for the initiation of hair follicle development. Dev Cell 2(5):643-653 
48. Zhang Y, Tomann P, Andl T, Gallant NM, Huelsken J, Jerchow B, Birchmeier W, Paus R, Piccolo S, Mikkola ML, Morrisey EE, Overbeek PA, Scheidereit C, Millar SE, Schmidt-Ullrich R (2009) Reciprocal requirements for EDA/EDAR/NF-kappaB and $\mathrm{Wnt} /$ beta-catenin signaling pathways in hair follicle induction. Dev Cell 17(1):49-61. doi:10.1016/j.devcel.2009.05.011

49. DasGupta R, Fuchs E (1999) Multiple roles for activated LEF/ TCF transcription complexes during hair follicle development and differentiation. Development 126(20):4557-4568

50. Gat U, DasGupta R, Degenstein L, Fuchs E (1998) De novo hair follicle morphogenesis and hair tumors in mice expressing a truncated beta-catenin in skin. Cell 95(5):605-614

51. Okuse T, Chiba T, Katsuumi I, Imai K (2005) Differential expression and localization of WNTs in an animal model of skin wound healing. Wound Repair Regen 13(5):491-497. doi:10.1111/ j.1067-1927.2005.00069.x

52. Labus MB, Stirk CM, Thompson WD, Melvin WT (1998) Expression of Wnt genes in early wound healing. Wound Repair Regen 6(1):58-64

53. Cheon SS, Wei Q, Gurung A, Youn A, Bright T, Poon R, Whetstone H, Guha A, Alman BA (2006) Beta-catenin regulates wound size and mediates the effect of TGF-beta in cutaneous healing. FASEB J 20(6):692-701. doi:10.1096/fj.05-4759com

54. Stojadinovic O, Brem H, Vouthounis C, Lee B, Fallon J, Stallcup M, Merchant A, Galiano RD, Tomic-Canic M (2005) Molecular pathogenesis of chronic wounds: the role of betacatenin and c-myc in the inhibition of epithelialization and wound healing. Am J Pathol 167(1):59-69

55. Cheon SS, Cheah AY, Turley S, Nadesan P, Poon R, Clevers H, Alman BA (2002) beta-Catenin stabilization dysregulates mesenchymal cell proliferation, motility, and invasiveness and causes aggressive fibromatosis and hyperplastic cutaneous wounds. Proc Natl Acad Sci USA 99(10):6973-6978. doi:10.1073/pnas. 102657399

56. Cheon S, Poon R, Yu C, Khoury M, Shenker R, Fish J, Alman BA (2005) Prolonged beta-catenin stabilization and tcf-dependent transcriptional activation in hyperplastic cutaneous wounds. Lab Invest 85(3):416-425. doi:10.1038/labinvest.3700237

57. Miragliotta V, Ipina Z, Lefebvre-Lavoie J, Lussier JG, Theoret CL (2008) Equine CTNNB1 and PECAM1 nucleotide structure and expression analyses in an experimental model of normal and pathological wound repair. BMC Physiol 8:1. doi:10.1186/14726793-8-1

58. Kapoor M, Liu S, Shi-wen X, Huh K, McCann M, Denton CP, Woodgett JR, Abraham DJ, Leask A (2008) GSK-3beta in mouse fibroblasts controls wound healing and fibrosis through an endothelin-1-dependent mechanism. J Clin Invest 118(10):3279-3290. doi:10.1172/JCI35381

59. Poon R, Nik SA, Ahn J, Slade L, Alman BA (2009) Beta-catenin and transforming growth factor beta have distinct roles regulating fibroblast cell motility and the induction of collagen lattice contraction. BMC Cell Biol 10:38. doi:10.1186/1471-2121-10-38

60. Amini-Nik S, Glancy D, Boimer C, Whetstone H, Keller C, Alman BA (2011) Pax7 expressing cells contribute to dermal wound repair; regulating scar size through a beta-catenin mediated process. Stem Cells 29(9):1371-1379. doi:10.1002/stem.688

61. Sato M (2006) Upregulation of the Wnt/beta-catenin pathway induced by transforming growth factor-beta in hypertrophic scars and keloids. Acta Derm Venereol 86(4):300-307. doi: 10.2340/00015555-0101

62. Bielefeld KA, Amini-Nik S, Whetstone H, Poon R, Youn A, Wang J, Alman BA (2011) Fibronectin and beta-catenin act in a regulatory loop in dermal fibroblasts to modulate cutaneous healing. J Biol Chem 286(31):27687-27697. doi:10.1074/jbc.M111. 261677
63. Bafico A, Liu G, Yaniv A, Gazit A, Aaronson SA (2001) Novel mechanism of Wnt signalling inhibition mediated by Dickkopf-1 interaction with LRP6/Arrow. Nat Cell Biol 3(7):683-686. doi: $10.1038 / 35083081$

64. Chen Y, Whetstone HC, Lin AC, Nadesan P, Wei Q, Poon R, Alman BA (2007) Beta-catenin signaling plays a disparate role in different phases of fracture repair: implications for therapy to improve bone healing. PLoS Med 4(7):e249. doi:10.1371/journal. pmed.0040249

65. Cheon SS, Nadesan P, Poon R, Alman BA (2004) Growth factors regulate beta-catenin-mediated TCF-dependent transcriptional activation in fibroblasts during the proliferative phase of wound healing. Exp Cell Res 293(2):267-274

66. Amini Nik S, Ebrahim RP, Van Dam K, Cassiman JJ, Tejpar S (2007) TGF-beta modulates beta-Catenin stability and signaling in mesenchymal proliferations. Exp Cell Res 313(13):2887-2895. doi:10.1016/j.yexcr.2007.05.024

67. Hynes RO (2002) Integrins: bidirectional, allosteric signaling machines. Cell 110(6):673-687

68. Berrier AL, Yamada KM (2007) Cell-matrix adhesion. J Cell Physiol 213(3):565-573. doi:10.1002/jcp.21237

69. Amini-Nik S, Kraemer D, Cowan ML, Gunaratne K, Nadesan P, Alman BA, Miller RJ (2010) Ultrafast mid-IR laser scalpel: protein signals of the fundamental limits to minimally invasive surgery. PLoS One 5(9). doi:10.1371/journal.pone.0013053

70. Alman BA, Kelley SP, Nam D (2011) Heal thyself: using endogenous regeneration to repair bone. Tissue Eng Part B Rev 17(6):431-436. doi:10.1089/ten.TEB.2011.0189

71. Alfaro MP, Saraswati S, Young PP (2011) Molecular mediators of mesenchymal stem cell biology. Vitam Horm 87:39-59. doi: 10.1016/B978-0-12-386015-6.00023-8

72. Augello A, De Bari C (2010) The regulation of differentiation in mesenchymal stem cells. Hum Gene Ther 21(10):1226-1238. doi:10.1089/hum.2010.173

73. Alfaro MP, Vincent A, Saraswati S, Thorne CA, Hong CC, Lee E, Young PP (2010) sFRP2 suppression of bone morphogenic protein (BMP) and Wnt signaling mediates mesenchymal stem cell (MSC) self-renewal promoting engraftment and myocardial repair. J Biol Chem 285(46):35645-35653. doi:10.1074/jbc.M110.135335

74. Collins CA, Kretzschmar K, Watt FM (2011) Reprogramming adult dermis to a neonatal state through epidermal activation of betacatenin. Development 138(23):5189-5199. doi:10.1242/dev.064592

75. Fujiwara H, Ferreira M, Donati G, Marciano DK, Linton JM, Sato Y, Hartner A, Sekiguchi K, Reichardt LF, Watt FM (2011) The basement membrane of hair follicle stem cells is a muscle cell niche. Cell 144(4):577-589. doi:10.1016/j.cell.2011.01.014

76. Barrientos S, Stojadinovic O, Golinko MS, Brem H, Tomic-Canic M (2008) Growth factors and cytokines in wound healing. Wound Repair Regen 16(5):585-601. doi:10.1111/j.1524-475X.2008. 00410.x

77. Schultz GS, Wysocki A (2009) Interactions between extracellular matrix and growth factors in wound healing. Wound Repair Regen 17(2):153-162. doi:10.1111/j.1524-475X.2009.00466.x

78. Owens P, Han G, Li AG, Wang XJ (2008) The role of Smads in skin development. J Invest Dermatol 128(4):783-790. doi:10.1038/ sj.jid.5700969

79. Margadant C, Sonnenberg A (2010) Integrin-TGF-beta crosstalk in fibrosis, cancer and wound healing. EMBO Rep 11(2):97-105. doi:10.1038/embor.2009.276

80. Biernacka A, Dobaczewski M, Frangogiannis NG (2011) TGFbeta signaling in fibrosis. Growth Factors 29(5):196-202. doi: 10.3109/08977194.2011.595714

81. Mu Y, Gudey SK, Landstrom M (2012) Non-Smad signaling pathways. Cell Tissue Res 347(1):11-20. doi:10.1007/s00441011-1201-y 
82. Landstrom M (2010) The TAK1-TRAF6 signalling pathway. Int J Biochem Cell Biol 42(5):585-589. doi:10.1016/j.biocel.2009. 12.023

83. Zhang YE (2009) Non-Smad pathways in TGF-beta signaling. Cell Res 19(1):128-139. doi:10.1038/cr.2008.328

84. Foitzik K, Paus R, Doetschman T, Dotto GP (1999) The TGFbeta2 isoform is both a required and sufficient inducer of murine hair follicle morphogenesis. Dev Biol 212(2):278-289. doi: 10.1006/dbio.1999.9325

85. Han G, Li AG, Liang YY, Owens P, He W, Lu S, Yoshimatsu Y, Wang D, Ten Dijke P, Lin X, Wang XJ (2006) Smad7-induced beta-catenin degradation alters epidermal appendage development. Dev Cell 11(3):301-312. doi:10.1016/j.devcel.2006.06. 014

86. Shah M, Foreman DM, Ferguson MW (1995) Neutralisation of TGF-beta 1 and TGF-beta 2 or exogenous addition of TGF-beta 3 to cutaneous rat wounds reduces scarring. J Cell Sci 108(Pt 3): 985-1002

87. Puolakkainen PA, Reed MJ, Gombotz WR, Twardzik DR, Abrass IB, Sage HE (1995) Acceleration of wound healing in aged rats by topical application of transforming growth factor-beta(1). Wound Repair Regen 3(3):330-339. doi:10.1046/j.1524-475X. 1995.t01-1-30314.x

88. Schreier T, Degen E, Baschong W (1993) Fibroblast migration and proliferation during in vitro wound healing. A quantitative comparison between various growth factors and a low molecular weight blood dialysate used in the clinic to normalize impaired wound healing. Res Exp Med (Berl) 193(4):195-205

89. Varga J, Rosenbloom J, Jimenez SA (1987) Transforming growth factor beta (TGF beta) causes a persistent increase in steady-state amounts of type I and type III collagen and fibronectin mRNAs in normal human dermal fibroblasts. Biochem $\mathrm{J}$ 247(3):597-604

90. Hocevar BA, Brown TL, Howe PH (1999) TGF-beta induces fibronectin synthesis through a c-Jun N-terminal kinase-dependent, Smad4-independent pathway. EMBO J 18(5):1345-1356. doi:10.1093/emboj/18.5.1345

91. Desmouliere A, Geinoz A, Gabbiani F, Gabbiani G (1993) Transforming growth factor-beta 1 induces alpha-smooth muscle actin expression in granulation tissue myofibroblasts and in quiescent and growing cultured fibroblasts. J Cell Biol 122(1): $103-111$

92. Martinez-Ferrer M, Afshar-Sherif AR, Uwamariya C, de Crombrugghe B, Davidson JM, Bhowmick NA (2010) Dermal transforming growth factor-beta responsiveness mediates wound contraction and epithelial closure. Am J Pathol 176(1):98-107. doi:10.2353/ajpath.2010.090283

93. Leask A (2011) CCN2: a bona fide target for anti-fibrotic drug intervention. J Cell Commun Signal 5(2):131-133. doi:10.1007/ s12079-011-0125-3

94. Trojanowska M (2009) Noncanonical transforming growth factor beta signaling in scleroderma fibrosis. Curr Opin Rheumatol 21(6):623-629. doi:10.1097/BOR.0b013e32833038ce

95. Cicha I, Goppelt-Struebe M (2009) Connective tissue growth factor: context-dependent functions and mechanisms of regulation. Biofactors 35(2):200-208. doi:10.1002/biof.30

96. Leask A, Parapuram SK, Shi-Wen X, Abraham DJ (2009) Connective tissue growth factor (CTGF, CCN2) gene regulation: a potent clinical bio-marker of fibroproliferative disease? J Cell Commun Signal 3(2):89-94. doi:10.1007/s12079-009-0037-7

97. Lee CH, Shah B, Moioli EK, Mao JJ (2010) CTGF directs fibroblast differentiation from human mesenchymal stem/stromal cells and defines connective tissue healing in a rodent injury model. J Clin Invest 120(9):3340-3349. doi:10.1172/JCI43230

98. Nakerakanti SS, Bujor AM, Trojanowska M (2011) CCN2 is required for the TGF-beta induced activation of Smad1-Erk1/2 signaling network. PLoS ONE 6(7):e21911. doi:10.1371/journal. pone.0021911

99. Duncan MR, Frazier KS, Abramson S, Williams S, Klapper H, Huang X, Grotendorst GR (1999) Connective tissue growth factor mediates transforming growth factor beta-induced collagen synthesis: down-regulation by cAMP. FASEB J 13(13): 1774-1786

100. Ashcroft GS, Yang X, Glick AB, Weinstein M, Letterio JL, Mizel DE, Anzano M, Greenwell-Wild T, Wahl SM, Deng C, Roberts AB (1999) Mice lacking Smad3 show accelerated wound healing and an impaired local inflammatory response. Nat Cell Biol 1(5):260-266. doi:10.1038/12971

101. Crowe MJ, Doetschman T, Greenhalgh DG (2000) Delayed wound healing in immunodeficient TGF-beta 1 knockout mice. J Invest Dermatol 115(1):3-11. doi:10.1046/j.1523-1747.2000.00010.x

102. Denton CP, Khan K, Hoyles RK, Shiwen X, Leoni P, Chen Y, Eastwood M, Abraham DJ (2009) Inducible lineage-specific deletion of TbetaRII in fibroblasts defines a pivotal regulatory role during adult skin wound healing. J Invest Dermatol 129(1):194-204. doi:10.1038/jid.2008.171

103. Pietenpol JA, Holt JT, Stein RW, Moses HL (1990) Transforming growth factor beta 1 suppression of c-myc gene transcription: role in inhibition of keratinocyte proliferation. Proc Natl Acad Sci USA 87(10):3758-3762

104. Reynolds LE, Conti FJ, Silva R, Robinson SD, Iyer V, Rudling R, Cross B, Nye E, Hart IR, Dipersio CM, Hodivala-Dilke KM (2008) alpha3beta1 integrin-controlled Smad7 regulates reepithelialization during wound healing in mice. J Clin Invest 118(3):965-974. doi:10.1172/JCI33538

105. Singer AJ, Huang SS, Huang JS, McClain SA, Romanov A, Rooney J, Zimmerman T (2009) A novel TGF-beta antagonist speeds reepithelialization and reduces scarring of partial thickness porcine burns. J Burn Care Res 30(2):329-334. doi: 10.1097/BCR.0b013e31819a6369

106. Han G, Li F, Ten Dijke P, Wang XJ (2011) Temporal smad7 transgene induction in mouse epidermis accelerates skin wound healing. Am J Pathol 179(4):1768-1779. doi:10.1016/j.ajpath.2011. 06.003

107. Yang CC, Lin SD, Yu HS (1997) Effect of growth factors on dermal fibroblast contraction in normal skin and hypertrophic scar. J Dermatol Sci 14(2):162-169

108. Mauviel A (2009) Transforming growth factor-beta signaling in skin: stromal to epithelial cross-talk. J Invest Dermatol 129(1):7-9. doi:10.1038/jid.2008.385

109. Le Poole IC, Boyce ST (1999) Keratinocytes suppress transforming growth factor-beta1 expression by fibroblasts in cultured skin substitutes. Br J Dermatol 140(3):409-416

110. Sisco M, Kryger ZB, O'Shaughnessy KD, Kim PS, Schultz GS, Ding XZ, Roy NK, Dean NM, Mustoe TA (2008) Antisense inhibition of connective tissue growth factor (CTGF/CCN2) mRNA limits hypertrophic scarring without affecting wound healing in vivo. Wound Repair Regen 16(5):661-673. doi: 10.1111/j.1524-475X.2008.00416.x

111. Lin RY, Adzick NS (1996) The role of the fetal fibroblast and transforming growth factor-beta in a model of human fetal wound repair. Semin Pediatr Surg 5(3):165-174

112. Scheid A, Wenger RH, Schaffer L, Camenisch I, Distler O, Ferenc A, Cristina H, Ryan HE, Johnson RS, Wagner KF, Stauffer UG, Bauer C, Gassmann M, Meuli M (2002) Physiologically low oxygen concentrations in fetal skin regulate hypoxia-inducible factor 1 and transforming growth factorbeta3. FASEB J 16(3):411-413. doi:10.1096/fj.01-0496fje

113. Nishi H, Nakada T, Hokamura M, Osakabe Y, Itokazu O, Huang LE, Isaka K (2004) Hypoxia-inducible factor-1 transactivates transforming growth factor-beta3 in trophoblast. Endocrinology 145(9):4113-4118. doi:10.1210/en.2003-1639 
114. Wu L, Siddiqui A, Morris DE, Cox DA, Roth SI, Mustoe TA (1997) Transforming growth factor beta 3 (TGF beta 3) accelerates wound healing without alteration of scar prominence. Histologic and competitive reverse-transcription-polymerase chain reaction studies. Arch Surg 132(7):753-760

115. Occleston NL, O'Kane S, Laverty HG, Cooper M, Fairlamb D, Mason T, Bush JA, Ferguson MW (2011) Discovery and development of avotermin (recombinant human transforming growth factor beta 3): a new class of prophylactic therapeutic for the improvement of scarring. Wound Repair Regen 19(Suppl 1):s38-s48. doi:10.1111/j.1524-475X.2011.00711.x

116. Bandyopadhyay B, Fan J, Guan S, Li Y, Chen M, Woodley DT, Li W (2006) A "traffic control" role for TGFbeta3: orchestrating dermal and epidermal cell motility during wound healing. J Cell Biol 172(7):1093-1105. doi:10.1083/jcb.200507111

117. Lorenz HP, Longaker MT, Perkocha LA, Jennings RW, Harrison MR, Adzick NS (1992) Scarless wound repair: a human fetal skin model. Development 114(1):253-259

118. McCollum PT, Bush JA, James G, Mason T, O'Kane S, McCollum C, Krievins D, Shiralkar S, Ferguson MW (2011) Randomized phase II clinical trial of avotermin versus placebo for scar improvement. Br J Surg 98(7):925-934. doi:10.1002/bjs.7438

119. Renovo (2011) www.renovo.com/en/news/juvista-eu-phase-3trial-results. Accessed 18 Sept 2012

120. Okuyama R, Tagami H, Aiba S (2008) Notch signaling: its role in epidermal homeostasis and in the pathogenesis of skin diseases. J Dermatol Sci 49(3):187-194. doi:10.1016/j.jdermsci.2007. 05.017

121. Watt FM, Estrach S, Ambler CA (2008) Epidermal Notch signalling: differentiation, cancer and adhesion. Curr Opin Cell Biol 20(2):171-179. doi:10.1016/j.ceb.2008.01.010

122. Gridley T (2010) Notch signaling in the vasculature. Curr Top Dev Biol 92:277-309. doi:10.1016/S0070-2153(10)92009-7

123. Blanpain C, Lowry WE, Pasolli HA, Fuchs E (2006) Canonical notch signaling functions as a commitment switch in the epidermal lineage. Genes Dev 20(21):3022-3035. doi:10.1101/ gad.1477606

124. Moriyama M, Durham AD, Moriyama H, Hasegawa K, Nishikawa S, Radtke F, Osawa M (2008) Multiple roles of Notch signaling in the regulation of epidermal development. Dev Cell 14(4):594-604. doi:10.1016/j.devcel.2008.01.017

125. Ezratty EJ, Stokes N, Chai S, Shah AS, Williams SE, Fuchs E (2011) A role for the primary cilium in Notch signaling and epidermal differentiation during skin development. Cell 145(7):1129-1141. doi:10.1016/j.cell.2011.05.030

126. Powell BC, Passmore EA, Nesci A, Dunn SM (1998) The Notch signalling pathway in hair growth. Mech Dev 78(1-2):189-192

127. Favier B, Fliniaux I, Thelu J, Viallet JP, Demarchez M, Jahoda CA, Dhouailly D (2000) Localisation of members of the notch system and the differentiation of vibrissa hair follicles: receptors, ligands, and fringe modulators. Dev Dyn 218(3):426-437. doi:10. 1002/1097-0177(200007)218:3<426:AID-DVDY1004>3.0.CO; $2-4$

128. Thelu J, Rossio P, Favier B (2002) Notch signalling is linked to epidermal cell differentiation level in basal cell carcinoma, psoriasis and wound healing. BMC Dermatol 2:7

129. Chigurupati S, Arumugam TV, Son TG, Lathia JD, Jameel S, Mughal MR, Tang SC, Jo DG, Camandola S, Giunta M, Rakova I, McDonnell N, Miele L, Mattson MP, Poosala S (2007) Involvement of notch signaling in wound healing. PLoS ONE 2(11):e1167. doi:10.1371/journal.pone.0001167

130. Outtz HH, Wu JK, Wang X, Kitajewski J (2010) Notch1 deficiency results in decreased inflammation during wound healing and regulates vascular endothelial growth factor receptor- 1 and inflammatory cytokine expression in macrophages. J Immunol 185(7):4363-4373. doi:10.4049/jimmunol.1000720
131. Caiado F, Real C, Carvalho T, Dias S (2008) Notch pathway modulation on bone marrow-derived vascular precursor cells regulates their angiogenic and wound healing potential. PLoS ONE 3(11):e3752. doi:10.1371/journal.pone.0003752

132. Athar M, Tang X, Lee JL, Kopelovich L, Kim AL (2006) Hedgehog signalling in skin development and cancer. Exp Dermatol 15(9):667-677. doi:10.1111/j.1600-0625.2006.004 73.x

133. Lavine KJ, White AC, Park C, Smith CS, Choi K, Long F, Hui CC, Ornitz DM (2006) Fibroblast growth factor signals regulate a wave of Hedgehog activation that is essential for coronary vascular development. Genes Dev 20(12):1651-1666. doi:10.1101/ gad.1411406

134. St-Jacques B, Dassule HR, Karavanova I, Botchkarev VA, Li J, Danielian PS, McMahon JA, Lewis PM, Paus R, McMahon AP (1998) Sonic hedgehog signaling is essential for hair development. Curr Biol 8(19):1058-1068

135. Karlsson L, Bondjers C, Betsholtz C (1999) Roles for PDGF-A and sonic hedgehog in development of mesenchymal components of the hair follicle. Development 126(12):2611-2621

136. Niemann C, Unden AB, Lyle S, Zouboulis ChC, Toftgard R, Watt FM (2003) Indian hedgehog and beta-catenin signaling: role in the sebaceous lineage of normal and neoplastic mammalian epidermis. Proc Natl Acad Sci USA 100(Suppl 1):11873-11880. doi:10.1073/pnas. 1834202100

137. Brownell I, Guevara E, Bai CB, Loomis CA, Joyner AL (2011) Nerve-derived sonic hedgehog defines a niche for hair follicle stem cells capable of becoming epidermal stem cells. Cell Stem Cell 8(5):552-565. doi:10.1016/j.stem.2011.02.021

138. Chiang C, Swan RZ, Grachtchouk M, Bolinger M, Litingtung Y, Robertson EK, Cooper MK, Gaffield W, Westphal H, Beachy PA, Dlugosz AA (1999) Essential role for Sonic hedgehog during hair follicle morphogenesis. Dev Biol 205(1):1-9. doi: 10.1006/dbio.1998.9103

139. Tasouri E, Tucker KL (2011) Primary cilia and organogenesis: is Hedgehog the only sculptor? Cell Tissue Res 345(1):21-40. doi:10.1007/s00441-011-1192-8

140. Asai J, Takenaka H, Kusano KF, Ii M, Luedemann C, Curry C, Eaton E, Iwakura A, Tsutsumi Y, Hamada H, Kishimoto S, Thorne T, Kishore R, Losordo DW (2006) Topical sonic hedgehog gene therapy accelerates wound healing in diabetes by enhancing endothelial progenitor cell-mediated microvascular remodeling. Circulation 113(20):2413-2424. doi:10.1161/CIRCULATION AHA.105.603167

141. Le H, Kleinerman R, Lerman OZ, Brown D, Galiano R, Gurtner GC, Warren SM, Levine JP, Saadeh PB (2008) Hedgehog signaling is essential for normal wound healing. Wound Repair Regen 16(6):768-773. doi:10.1111/j.1524-475X.2008.00430.x

142. Levy V, Lindon C, Zheng Y, Harfe BD, Morgan BA (2007) Epidermal stem cells arise from the hair follicle after wounding. FASEB J 21(7):1358-1366. doi:10.1096/fj.06-6926com

143. Luo JD, Hu TP, Wang L, Chen MS, Liu SM, Chen AF (2009) Sonic hedgehog improves delayed wound healing via enhancing cutaneous nitric oxide function in diabetes. Am J Physiol Endocrinol Metab 297(2):E525-E531. doi:10.1152/ajpendo.00308.2009

144. Hoffmann JA, Reichhart JM (2002) Drosophila innate immunity: an evolutionary perspective. Nat Immunol 3(2):121-126. doi:10.1038/ni0202-121

145. Nichols SA, Dirks W, Pearse JS, King N (2006) Early evolution of animal cell signaling and adhesion genes. Proc Natl Acad Sci USA 103(33):12451-12456. doi:10.1073/pnas.0604065103

146. Carlson BM (2005) Some principles of regeneration in mammalian systems. Anat Rec B New Anat 287(1):4-13. doi: 10.1002/ar.b.20079

147. Han M, Yang X, Taylor G, Burdsal CA, Anderson RA, Muneoka K (2005) Limb regeneration in higher vertebrates: 
developing a roadmap. Anat Rec B New Anat 287(1):14-24. doi:10.1002/ar.b.20082

148. Sanchez Alvarado A (2006) Planarian regeneration: its end is its beginning. Cell 124(2):241-245. doi:10.1016/j.cell.2006.01.012

149. Petersen CP, Reddien PW (2011) Polarized notum activation at wounds inhibits Wnt function to promote planarian head regeneration. Science 332(6031):852-855. doi:10.1126/science. 1202143

150. Adell T, Salo E, Boutros M, Bartscherer K (2009) Smed-Evi/ Wntless is required for beta-catenin-dependent and -independent processes during planarian regeneration. Development 136(6): 905-910. doi:10.1242/dev.033761

151. De Robertis EM (2010) Wnt signaling in axial patterning and regeneration: lessons from planaria. Sci Signal 3(127):pe21. doi: 10.1126/scisignal.3127pe21

152. Yazawa S, Umesono Y, Hayashi T, Tarui H, Agata K (2009) Planarian Hedgehog/Patched establishes anterior-posterior polarity by regulating Wnt signaling. Proc Natl Acad Sci USA 106(52):22329-22334. doi:10.1073/pnas.0907464106

153. Mace KA, Pearson JC, McGinnis W (2005) An epidermal barrier wound repair pathway in Drosophila is mediated by grainy head. Science 308(5720):381-385. doi:10.1126/science. 1107573

154. Ting SB, Caddy J, Hislop N, Wilanowski T, Auden A, Zhao LL, Ellis S, Kaur P, Uchida Y, Holleran WM, Elias PM, Cunningham JM, Jane SM (2005) A homolog of Drosophila grainy head is essential for epidermal integrity in mice. Science 308(5720): 411-413. doi:10.1126/science.1107511

155. Woolner S, Jacinto A, Martin P (2005) The small GTPase Rac plays multiple roles in epithelial sheet fusion-dynamic studies of Drosophila dorsal closure. Dev Biol 282(1):163-173. doi: 10.1016/j.ydbio.2005.03.005

156. Samakovlis C, Manning G, Steneberg P, Hacohen N, Cantera R, Krasnow MA (1996) Genetic control of epithelial tube fusion during Drosophila tracheal development. Development 122(11): 3531-3536

157. Harden N (2002) Signaling pathways directing the movement and fusion of epithelial sheets: lessons from dorsal closure in Drosophila. Differentiation 70(4-5):181-203. doi:10.1046/j.1432-0436. 2002.700408.x

158. McEwen DG, Cox RT, Peifer M (2000) The canonical Wg and JNK signaling cascades collaborate to promote both dorsal closure and ventral patterning. Development 127(16):3607-3617

159. Childs SR, Wrana JL, Arora K, Attisano L, O'Connor MB, Massague J (1993) Identification of a Drosophila activin receptor. Proc Natl Acad Sci USA 90(20):9475-9479

160. Brummel TJ, Twombly V, Marques G, Wrana JL, Newfeld SJ, Attisano L, Massague J, O'Connor MB, Gelbart WM (1994) Characterization and relationship of Dpp receptors encoded by the saxophone and thick veins genes in Drosophila. Cell 78(2):251-261

161. Shao J, Qian X, Zhang C, Xu Z (2009) Fin regeneration from tail segment with musculature, endoskeleton, and scales. J Exp Zool B Mol Dev Evol 312(7):762-769. doi:10.1002/jez.b.21295

162. Yoshinari N, Kawakami A (2011) Mature and juvenile tissue models of regeneration in small fish species. Biol Bull 221(1): $62-78$

163. Santos-Ruiz L, Santamaria JA, Ruiz-Sanchez J, Becerra J (2002) Cell proliferation during blastema formation in the regenerating teleost fin. Dev Dyn 223(2):262-272. doi:10.1002/dvdy.10055

164. Quint E, Smith A, Avaron F, Laforest L, Miles J, Gaffield W, Akimenko MA (2002) Bone patterning is altered in the regenerating zebrafish caudal fin after ectopic expression of sonic hedgehog and bmp2b or exposure to cyclopamine. Proc Natl Acad Sci USA 99(13):8713-8718. doi:10.1073/pnas.122571799
165. Poss KD, Shen J, Nechiporuk A, McMahon G, Thisse B, Thisse C, Keating MT (2000) Roles for Fgf signaling during zebrafish fin regeneration. Dev Biol 222(2):347-358. doi:10.1006/dbio.2000. 9722

166. Stoick-Cooper CL, Weidinger G, Riehle KJ, Hubbert C, Major MB, Fausto N, Moon RT (2007) Distinct Wnt signaling pathways have opposing roles in appendage regeneration. Development 134(3):479-489. doi:10.1242/dev.001123

167. Bai S, Thummel R, Godwin AR, Nagase H, Itoh Y, Li L, Evans R, McDermott J, Seiki M, Sarras MP Jr (2005) Matrix metalloproteinase expression and function during fin regeneration in zebrafish: analysis of MT1-MMP, MMP2 and TIMP2. Matrix Biol 24(4):247-260. doi:10.1016/j.matbio.2005.03.007

168. Brockes JP, Kumar A (2002) Plasticity and reprogramming of differentiated cells in amphibian regeneration. Nat Rev Mol Cell Biol 3(8):566-574. doi:10.1038/nrm881

169. Suzuki M, Satoh A, Ide H, Tamura K (2005) Nerve-dependent and -independent events in blastema formation during Xenopus froglet limb regeneration. Dev Biol 286(1):361-375. doi:10. 1016/j.ydbio.2005.08.021

170. Young HE, Duplaa C, Romero-Ramos M, Chesselet MF, Vourc'h P, Yost MJ, Ericson K, Terracio L, Asahara T, Masuda H, Tamura-Ninomiya S, Detmer K, Bray RA, Steele TA, Hixson D, el-Kalay M, Tobin BW, Russ RD, Horst MN, Floyd JA, Henson NL, Hawkins KC, Groom J, Parikh A, Blake L, Bland LJ, Thompson AJ, Kirincich A, Moreau C, Hudson J, Bowyer FP 3rd, Lin TJ, Black AC Jr (2004) Adult reserve stem cells and their potential for tissue engineering. Cell Biochem Biophys 40(1):1-80. doi:10.1385/CBB:40:1:1

171. Kragl M, Knapp D, Nacu E, Khattak S, Maden M, Epperlein HH, Tanaka EM (2009) Cells keep a memory of their tissue origin during axolotl limb regeneration. Nature 460(7251):60-65. doi: 10.1038 /nature08152

172. Beck CW, Izpisua Belmonte JC, Christen B (2009) Beyond early development: Xenopus as an emerging model for the study of regenerative mechanisms. Dev Dyn 238(6):1226-1248. doi: $10.1002 /$ dvdy. 21890

173. Kawakami Y, Rodriguez Esteban C, Raya M, Kawakami H, Marti M, Dubova I, Izpisua Belmonte JC (2006) Wnt/betacatenin signaling regulates vertebrate limb regeneration. Genes Dev 20(23):3232-3237. doi:10.1101/gad.1475106

174. Polychronopoulos $\mathrm{P}$, Magiatis $\mathrm{P}$, Skaltsounis AL, Myrianthopoulos V, Mikros E, Tarricone A, Musacchio A, Roe SM, Pearl L, Leost M, Greengard P, Meijer L (2004) Structural basis for the synthesis of indirubins as potent and selective inhibitors of glycogen synthase kinase-3 and cyclin-dependent kinases. J Med Chem 47(4):935-946. doi:10.1021/jm031016d

175. Lin G, Slack JM (2008) Requirement for Wnt and FGF signaling in Xenopus tadpole tail regeneration. Dev Biol 316(2):323-335. doi:10.1016/j.ydbio.2008.01.032

176. Beck CW, Christen B, Slack JM (2003) Molecular pathways needed for regeneration of spinal cord and muscle in a vertebrate. Dev Cell 5(3):429-439

177. Schnapp E, Kragl M, Rubin L, Tanaka EM (2005) Hedgehog signaling controls dorsoventral patterning, blastema cell proliferation and cartilage induction during axolotl tail regeneration. Development 132(14):3243-3253. doi:10.1242/dev.01906

178. Ho DM, Whitman M (2008) TGF-beta signaling is required for multiple processes during Xenopus tail regeneration. Dev Biol 315(1):203-216. doi:10.1016/j.ydbio.2007.12.031

179. McCusker C, Gardiner DM (2011) The axolotl model for regeneration and aging research: a mini-review. Gerontology 57(6):565-571. doi:10.1159/000323761

180. Seifert AW, Monaghan JR, Voss SR, Maden M (2012) Skin regeneration in adult axolotls: a blueprint for scar-free healing in 
vertebrates. PLoS ONE 7(4):e32875. doi:10.1371/journal.pone. 0032875

181. Gardiner DM (2005) Ontogenetic decline of regenerative ability and the stimulation of human regeneration. Rejuvenation Res 8(3):141-153. doi:10.1089/rej.2005.8.141

182. Bruckner-Tuderman L (2010) Systemic therapy for a genetic skin disease. N Engl J Med 363(7):680-682. doi:10.1056/NEJMe 1004319

183. Sen CK, Gordillo GM, Roy S, Kirsner R, Lambert L, Hunt TK, Gottrup F, Gurtner GC, Longaker MT (2009) Human skin wounds: a major and snowballing threat to public health and the economy. Wound Repair Regen 17(6):763-771. doi:10.1111/j.1524475X.2009.00543.x

184. Cheng CF, Sahu D, Tsen F, Zhao Z, Fan J, Kim R, Wang X, O'Brien K, Li Y, Kuang Y, Chen M, Woodley DT, Li W (2011) A fragment of secreted Hsp90alpha carries properties that enable it to accelerate effectively both acute and diabetic wound healing in mice. J Clin Invest 121(11):4348-4361. doi:10.1172/ JCI46475

185. Tuan TL, Nichter LS (1998) The molecular basis of keloid and hypertrophic scar formation. Mol Med Today 4(1):19-24. doi: 10.1016/S1357-4310(97)80541-2

186. Chin GS, Liu W, Peled Z, Lee TY, Steinbrech DS, Hsu M, Longaker MT (2001) Differential expression of transforming growth factor-beta receptors I and II and activation of Smad 3 in keloid fibroblasts. Plast Reconstr Surg 108(2):423-429

187. Lee TY, Chin GS, Kim WJ, Chau D, Gittes GK, Longaker MT (1999) Expression of transforming growth factor beta 1, 2, and 3 proteins in keloids. Ann Plast Surg 43(2):179-184

188. Phan TT, Lim IJ, Aalami O, Lorget F, Khoo A, Tan EK, Mukhopadhyay A, Longaker MT (2005) Smad3 signalling plays an important role in keloid pathogenesis via epithelial-mesenchymal interactions. J Pathol 207(2):232-242. doi:10.1002/path. 1826

189. Yu H, Bock O, Bayat A, Ferguson MW, Mrowietz U (2006) Decreased expression of inhibitory SMAD6 and SMAD7 in keloid scarring. J Plast Reconstr Aesthet Surg 59(3):221-229

190. Wei Q, Yokota C, Semenov MV, Doble B, Woodgett J, He X (2007) R-spondin1 is a high affinity ligand for LRP6 and induces LRP6 phosphorylation and beta-catenin signaling. J Biol Chem 282(21):15903-15911. doi:10.1074/jbc.M7019 27200

191. Chua AW, Ma D, Gan SU, Fu Z, Han HC, Song C, Sabapathy K, Phan TT (2011) The role of R-spondin2 in keratinocyte proliferation and epidermal thickening in keloid scarring. $\mathrm{J}$ Invest Dermatol 131(3):644-654. doi:10.1038/jid.2010.371

192. Kim A, DiCarlo J, Cohen C, McCall C, Johnson D, McAlpine B, Quinn AG, McLaughlin ER, Arbiser JL (2001) Are keloids really "gli-loids"?: High-level expression of gli-1 oncogene in keloids. J Am Acad Dermatol 45(5):707-711. doi:10.1067/mjd.2001. 117736

193. Werner S, Grose R (2003) Regulation of wound healing by growth factors and cytokines. Physiol Rev 83(3):835-870. doi: 10.1152 /physrev.00031.2002

194. Grose R, Werner S (2003) Wound healing studies in transgenic and knockout mice. A review. Methods Mol Med 78:191-216. doi:10.1385/1-59259-332-1:191

195. Brown GL, Nanney LB, Griffen J, Cramer AB, Yancey JM, Curtsinger LJ 3rd, Holtzin L, Schultz GS, Jurkiewicz MJ, Lynch JB (1989) Enhancement of wound healing by topical treatment with epidermal growth factor. N Engl J Med 321(2):76-79. doi: 10.1056/NEJM198907133210203

196. Mohan VK (2007) Recombinant human epidermal growth factor (REGEN-D 150): effect on healing of diabetic foot ulcers. Diabetes Res Clin Pract 78(3):405-411. doi:10.1016/j.diabres.2007.06.004
197. Fu X, Shen Z, Chen Y, Xie J, Guo Z, Zhang M, Sheng Z (1998) Randomised placebo-controlled trial of use of topical recombinant bovine basic fibroblast growth factor for second-degree burns. Lancet 352(9141):1661-1664. doi:10.1016/S0140-673 6(98)01260-4

198. Lin RY, Sullivan KM, Argenta PA, Meuli M, Lorenz HP, Adzick NS (1995) Exogenous transforming growth factor-beta amplifies its own expression and induces scar formation in a model of human fetal skin repair. Ann Surg 222(2):146-154

199. Ghahary A, Shen YJ, Scott PG, Gong Y, Tredget EE (1993) Enhanced expression of mRNA for transforming growth factorbeta, type I and type III procollagen in human post-burn hypertrophic scar tissues. J Lab Clin Med 122(4):465-473

200. Ferguson MW, O'Kane S (2004) Scar-free healing: from embryonic mechanisms to adult therapeutic intervention. Philos Trans R Soc Lond B Biol Sci 359(1445):839-850. doi:10.1098/rstb. 2004.1475

201. Robson MC, Phillip LG, Cooper DM, Lyle WG, Robson LE, Odom L, Hill DP, Hanham AF, Ksander GA (1995) Safety and effect of transforming growth factor-beta(2) for treatment of venous stasis ulcers. Wound Repair Regen 3(2):157-167. doi: 10.1046/j.1524-475X.1995.30207.x

202. So K, McGrouther DA, Bush JA, Durani P, Taylor L, Skotny G, Mason T, Metcalfe A, O'Kane S, Ferguson MW (2011) Avotermin for scar improvement following scar revision surgery: a randomized, double-blind, within-patient, placebo-controlled, phase II clinical trial. Plast Reconstr Surg 128(1):163-172. doi: 10.1097/PRS.0b013e318217429b

203. LeGrand EK (1998) Preclinical promise of becaplermin (rhPDGF-BB) in wound healing. Am J Surg 176 (2A Suppl): 48S-54S

204. Mandracchia VJ, Sanders SM, Frerichs JA (2001) The use of becaplermin (rhPDGF-BB) gel for chronic nonhealing ulcers. A retrospective analysis. Clin Podiatr Med Surg 18 (1):189-209, viii

205. Smiell JM, Wieman TJ, Steed DL, Perry BH, Sampson AR, Schwab BH (1999) Efficacy and safety of becaplermin (recombinant human platelet-derived growth factor-BB) in patients with nonhealing, lower extremity diabetic ulcers: a combined analysis of four randomized studies. Wound Repair Regen 7(5):335-346

206. Ono I, Akasaka Y, Kikuchi R, Sakemoto A, Kamiya T, Yamashita T, Jimbow K (2007) Basic fibroblast growth factor reduces scar formation in acute incisional wounds. Wound Repair Regen 15(5):617-623. doi:10.1111/j.1524-475X.2007.00293.x

207. Berlanga-Acosta J, Gavilondo-Cowley J, Lopez-Saura P, Gonzalez-Lopez T, Castro-Santana MD, Lopez-Mola E, Guillen-Nieto G, Herrera-Martinez L (2009) Epidermal growth factor in clinical practice - a review of its biological actions, clinical indications and safety implications. Int Wound $\mathrm{J}$ 6(5):331-346. doi:10.1111/j.1742-481X.2009.00622.x

208. Martino MM, Tortelli F, Mochizuki M, Traub S, Ben-David D, Kuhn GA, Muller R, Livne E, Eming SA, Hubbell JA (2011) Engineering the growth factor microenvironment with fibronectin domains to promote wound and bone tissue healing. Sci Transl Med 3 (100):100ra189. doi:10.1126/scitranslmed.3002614

209. Wadman M (2005) Scar prevention: the healing touch. Nature 436(7054):1079-1080. doi:10.1038/4361079a

210. Vrijman C, van Drooge AM, Limpens J, Bos JD, van der Veen JP, Spuls PI, Wolkerstorfer A (2011) Laser and intense pulsed light therapy for the treatment of hypertrophic scars: a systematic review. Br J Dermatol 165(5):934-942. doi:10.1111/j.1365-2133.2011. 10492.x

211. Alster TS, West TB (1997) Treatment of scars: a review. Ann Plast Surg 39(4):418-432 
212. Solon LR, Aronson R, Gould G (1961) Physiological implications of laser beams. Science 134:1506-1508

213. Capon A, Mordon S (2003) Can thermal lasers promote skin wound healing? Am J Clin Dermatol 4(1):1-12

214. Cooper L, Johnson C, Burslem F, Martin P (2005) Wound healing and inflammation genes revealed by array analysis of 'macrophageless' PU.1 null mice. Genome Biol 6(1):R5. doi: 10.1186/gb-2004-6-1-r5

215. Colwell AS, Longaker MT, Peter Lorenz H (2008) Identification of differentially regulated genes in fetal wounds during regenerative repair. Wound Repair Regen 16(3):450-459. doi:10.1111/j. 1524-475X.2008.00383.x

216. Roy S, Sen CK (2012) miRNA in wound inflammation and angiogenesis. Microcirculation 19(3):224-232. doi:10.1111/j.15498719.2011.00156.x
217. Richardson RL, Wright JT, Kim JW, Hausman GJ (1992) Expression of transforming growth factor-beta (TGF-beta 1) and insulin-like growth factor II (IGF-II) messenger RNA in the developing subcutaneous tissue (SQ) of the fetal pig. Growth Dev Aging 56(3):149-157

218. Porras-Reyes BH, Ksander G, Weeks PM (1993) Occurrence and localization of transforming growth factor-beta (TGF-beta 1 , beta 2) during rabbit skin development. Connect Tissue Res 29(3):203-212

219. Olivera-Martinez I, Thelu J, Teillet MA, Dhouailly D (2001) Dorsal dermis development depends on a signal from the dorsal neural tube, which can be substituted by Wnt-1. Mech Dev 100(2):233-244 